\title{
Recent Advances in Understanding Mechanisms of Plant Tolerance and Response to Aluminum Toxicity
}

\author{
Yunmin Wei, Rongrong Han, Yonghong Xie, Caode Jiang and Yongxiong Yu *
}

College of Animal Science and Technology, Southwest University, Chongqing 400715, China; weiym1024@163.com (Y.W.); 19891214rong@163.com (R.H.); Xieyh0128@163.com (Y.X.); jcdpjx@swu.edu.cn (C.J.)

* Correspondence: yuyongxiong8@126.com; Tel.: +86-138-8360-8535

check for updates

Citation: Wei, Y.; Han, R.; Xie, Y.; Jiang, C.; Yu, Y. Recent Advances in Understanding Mechanisms of Plant Tolerance and Response to Aluminum Toxicity. Sustainability 2021, 13, 1782. https://doi.org/ $10.3390 /$ su13041782

Academic Editors: Maria De Nobili and Marc A. Rosen

Received: 31 December 2020

Accepted: 29 January 2021

Published: 7 February 2021

Publisher's Note: MDPI stays neutral with regard to jurisdictional claims in published maps and institutional affiliations.

Copyright: (c) 2021 by the authors. Licensee MDPI, Basel, Switzerland. This article is an open access article distributed under the terms and conditions of the Creative Commons Attribution (CC BY) license (https:// creativecommons.org/licenses/by/ $4.0 /)$.
Abstract: Aluminum (Al) toxicity is a major environmental stress that inhibits plant growth and development. There has been impressive progress in recent years that has greatly increased our understanding of the nature of $\mathrm{Al}$ toxicity and its mechanisms of tolerance. This review describes the transcription factors (TFs) and plant hormones involved in the adaptation to Al stress. In particular, it discusses strategies to confer plant resistance to Al stress, such as transgenic breeding, as well as small molecules and plant growth-promoting rhizobacteria (PGPRs) to alleviate Al toxicity. This paper provides a theoretical basis for the enhancement of plant production in acidic soils.

Keywords: Al toxicity; Al tolerance mechanism; Al tolerance strategy

\section{Introduction}

Aluminum ( $\mathrm{Al})$ is the third most abundant chemical element in the earth's crust. Al mainly exists as aluminosilicates and oxides with non-phytotoxicity in neutral or slightly acidic soils. In acidic conditions $(\mathrm{pH}<5.0)$, the mineral form of $\mathrm{Al}$ dissolves to release the soluble $\mathrm{Al}^{3+}$ species, which can rapidly inhibit root elongation and further affect the uptake of water and nutrients, eventually resulting in nutritional deficiency and drought stress, which lead to severe loss of plant productivity [1,2]. Acidic soils occupy approximately $50 \%$ of potentially arable lands worldwide, most of which are distributed in Southwest Asia, Central Africa, and South America, as well as in Australia, eastern North America, and throughout Europe $[3,4]$. In recent decades, with an increasing intensity of human activities, especially an increase in acid deposition caused by global industrialization and the high-intensity utilization of agricultural soil have led to the continuous entry of a large amount of exogenous $\mathrm{H}^{+}$into the soil, which has greatly accelerated the process of soil acidification, raising a huge threat to sustainable agricultural development and food security [5]. Liming can ameliorate $\mathrm{Al}$ toxicity by raising the soil $\mathrm{pH}$, but it has little effect on the improvement of the underlying soil and hardens the soil structure [6]. The world's population is also growing rapidly and is anticipated to increase to 9.7 billion by 2050 [7]. Therefore, understanding Al-resistance mechanisms and the development of strategies to confer plant resistance for sustainable agricultural productivity remains imperative.

The research on Al stress has been updated rapidly in recent years, and a substantial number of new genes have been proven to be involved. For example, Snowden et al. cloned five wali1-5 (wheat aluminum induced) genes from the root tips of Al-treated Warigal wheat (Triticum aestivum) [8]. Subsequently, Richards et al. cloned wali6 and wali7 in this variety of wheat [9]. However, there are limited reviews on Al stress. Furthermore, more and more evidence has confirmed the involvement and roles of $\mathrm{Al}$ in promoting plant growth, improving phosphorus efficiency, and alleviating $\mathrm{H}^{+}$, manganese, and iron toxicities in acidic conditions $[10,11]$. Additionally, Al stress confers plants tolerance to abiotic stresses by activating the stress-related genes and attracts the plant growth-promoting rhizobacteria (PGPRs) toward roots by inducing root exudates $[10,12]$. Therefore, more reviews on the progress of research on Al stress are needed. This paper comprehensively reviews recent 
advances by studies on $\mathrm{Al}$ toxicity and tolerance in plants, thereby providing a theoretical basis for the cultivation of $\mathrm{Al}$ tolerant varieties.

\section{Effects of Aluminum (Al) Stress in Plants}

$\mathrm{Al}$ stress has become the main limiting factor with multifarious detrimental effects in plants (Figure 1). The $\mathrm{Al}^{3+}$ ion is a multivalent cation that rapidly and strongly binds to negatively charged sites in the root [13]. It has been reported that $\mathrm{Al}$ changes the properties of the cell wall (CW) and interferes with the transport of molecules across the cell membrane, influencing an array of intercellular processes [14]. The major target site of Al toxicity is the root apex, particularly the distal part of the transition zone [15]. Al binding of the root causes loss of $\mathrm{Mg}^{2+}, \mathrm{K}^{+}$, and $\mathrm{Ca}^{2+}$, as well as limits the availability of indispensable nutrients, especially phosphorus $(\mathrm{P})$, magnesium $(\mathrm{Mg})$, and molybdenum $(\mathrm{Mo})$, therefore, impairing root growth [16,17]. Al also reduces expansion, stomatal closure, and net photosynthesis in leaves, and tends to bind with $\mathrm{P}$ to form insoluble complexes in acidic soil, thereby resulting in $\mathrm{P}$ deficiency for plant growth [18,19]. Likewise, Al stress decreases the phytoextraction capability from contaminated soils using hyperaccumulators [20]. Moreover, Al stress can cause the production of reactive oxygen species (ROS) and reactive nitrogen species (RNS), which trigger a series of free radical chain reactions, including the peroxidation of the cell membrane system, decrease in enzyme activities, decomposition of chlorophyll, and breakage of the DNA strand [21]. Recently, Al stress has been reported to disturb soil rhizobia by affecting the efficacy of nodulation and $\mathrm{N}$-fixation in legume species, and therefore influences the balance of hormones in plant roots, which has been proposed to cause growth inhibition [22,23]. Intriguingly, $\mathrm{Al}^{3+}$ has been regarded as a beneficial element in the growth of some plants in acidic soil, and Al-induced growth enhancement in tea plants has been associated with the maintenance of DNA integrity in meristematic cells and increased uptake of nutrient elements $[10,24,25]$.

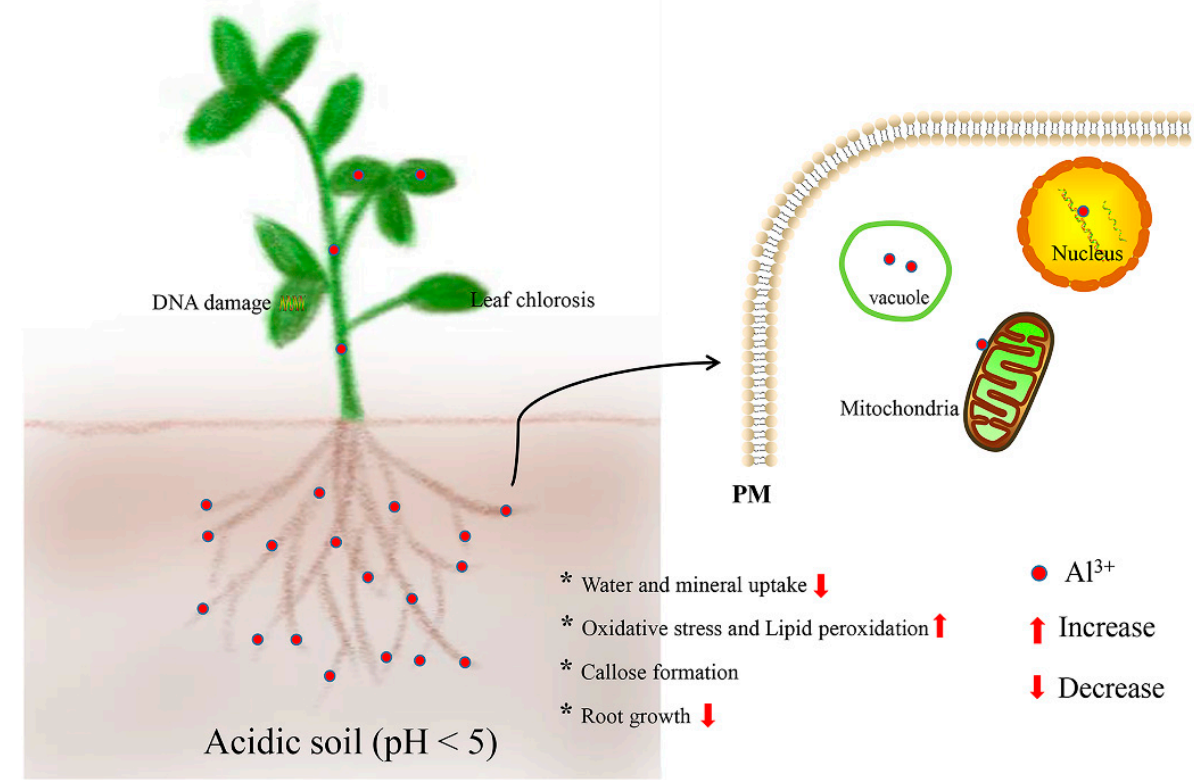

Figure 1. Adverse detrimental effects of aluminum ( $\mathrm{Al})$ stress and their location in plants.

\section{Al Tolerance Mechanisms in Plants}

Plants thriving in acidic soil have adaptations, including external exclusion and internal tolerance, to detoxify $\mathrm{Al}[3,26]$. External exclusion prevents $\mathrm{Al}$ from entering cells through Al-induced root exudation of organic compounds into the rhizosphere, decreasing the capacity of $\mathrm{CWs}$ to bind $\mathrm{Al}^{3+}$ and rhizosphere alkalization. Internal tolerance mainly includes the uptake and sequestration of $\mathrm{Al}$ in the vacuole and the improvement of antioxidant capacity inside cells $[5,27]$. Recently, various approaches have been used to 
study the mechanisms of $\mathrm{Al}$ tolerance in plants. Transcriptome, proteome, metabolome, mutation breeding methodologies, and several Al-tolerant genes have been reported to be involved in the secretion of organic acids (OAs) for $\mathrm{Al}^{3+}$ chelation, $\mathrm{CW}$ modification for the reduction in $\mathrm{Al}$ content, $\mathrm{pH}$ increase in the rhizosphere, etc. (Table 1).

Table 1. Genes confirmed to be involved in $\mathrm{Al}$ tolerance in recent years.

\begin{tabular}{|c|c|c|c|c|}
\hline Genes & Description & Plant Species & Functions & References \\
\hline AhFRDL1 & $\begin{array}{l}\text { Ferric reductase defective-like } 1 \\
\text { protein }\end{array}$ & Arachis hypogaea & Transport citrate & [28] \\
\hline AtPrx 64 & Class III peroxidase & Arabidopsis thatiana & Peroxidase & [29] \\
\hline AvSAMS1 & $\begin{array}{l}\text { S-adenosyl methionine } \\
\text { synthetase }\end{array}$ & Andropogon virginicus & Alterations of methylation status & {$[30]$} \\
\hline BoALMT1 & $\begin{array}{l}\text { Aluminum induced malate } \\
\text { transporter }\end{array}$ & Brassica oleracea & Transport malate & {$[31]$} \\
\hline$B d M A T E$ & & Brachypodium distachyon & & [32] \\
\hline GmMATE75 & & Glycine $\max$ & & {$[33]$} \\
\hline GmMATE79 & & Glycine max & & {$[33]$} \\
\hline GmMATE87 & Multidrug and toxic compound & Glycine max & Transnort citrate & [33] \\
\hline GsMATE & extrusion & Glycine soja & Iransport citrate & {$[34]$} \\
\hline PtrMATE1 & & Populus tomentosa & & [35] \\
\hline PtrMATE2 & & Populus tomentosa & & [35] \\
\hline TaMATE1B & & Triticum aestivum & & [36] \\
\hline FeSTAR1 & Half-type $A B C$ transporter & Fagopyrum esculentum & $\begin{array}{l}\text { Affect cell wall hemicellulose } \\
\text { metabolism }\end{array}$ & [37] \\
\hline GmGRPL & Glycine-rich protein-like protein & Glycine max & $\begin{array}{l}\text { Regulating the level of } \\
\text { indole-3-acetic acid (IAA) and } \\
\text { ethylene }\end{array}$ & [38] \\
\hline GmIREG3 & Iron regulated/ferroportin & Glycine max & $\begin{array}{c}\text { Sequestrating } \mathrm{Al} \text { into the } \\
\text { vacuoles }\end{array}$ & [39] \\
\hline GmME1 & NADP-malic enzyme & Glycine max & NADP-malic enzyme activity & {$[40]$} \\
\hline$H t N H X 1$ & Sodium (potassium)/proton & Helianthus tuberosus & & [41] \\
\hline HtNHX2 & antiporters & Helianthus tuberosus & $\mathrm{Na}+/ \mathrm{H}+$ antiporter & [41] \\
\hline$H v A B C B 25$ & $\begin{array}{l}\text { ATP binding cassette } \\
\text { transporters }\end{array}$ & Hordeum vulgare & Vacuolar Al sequestration & [42] \\
\hline $\mathrm{MsCS}$ & Citrate synthase & Medicago sativa & Citrate synthesis & [43] \\
\hline$M s P G$ & Polygalacturonase & Medicago sativa & $\begin{array}{l}\text { Decreasing } \mathrm{Al} \text { accumulation and } \\
\text { increasing porosity and } \\
\text { extensibility of cell walls }\end{array}$ & [44] \\
\hline NtSUT1 & Sucrose transporter & Nicotiana tabacum & Sucrose uptake & [45] \\
\hline OsAUX3 & Auxin carrier & Oryza sativa & Auxin influx carrier & [46] \\
\hline VUAAE3 & Acyl activating enzyme & Vigna umbellata & Oxalyl-CoA synthetase & [47] \\
\hline$V u F D H$ & Formate dehydrogenase & Vigna umbellata & $\begin{array}{l}\text { Catalyze the oxidation of } \\
\text { formate }\end{array}$ & [48] \\
\hline $\mathrm{ZjOMT}$ & Methyltransferase & Zoysia japonica & Melatonin synthesis & [49] \\
\hline ZmAT6 & Aluminum tolerance protein & Zea mays & $\begin{array}{l}\text { Scavenging reactive oxygen } \\
\text { species }\end{array}$ & [50] \\
\hline ZmPGP1 & P-glycoprotein & Zea mays & Auxin efflux carrier & [51] \\
\hline
\end{tabular}

\subsection{External Exclusion Mechanisms}

In the Al tolerance mechanism, plants can secrete OAs, such as citrate, malate, and oxalate, from roots under $\mathrm{Al}$ stress [3,26,52]. Accumulating evidence has shown that citrate is more dominant than malate and oxalate in response to Al stress [3]. Al-induced secretion of OAs is mediated through anion channels or transporters [53]. To date, Al-activated malate transporter (ALMT) and multidrug and toxic compound extrusion (MATE) have been identified $[5,16,17,27]$. Since Sasaki et al. identified TaALMT1 from wheat [54], it has been discovered that ALMT is involved in Al-induced secretion of malate to alleviate Al toxicity in Arabidopsis [55,56], barley (Hordeum vulgare) [57], rape (Brassica napus) [58,59], maize (Zea mays) [60], Yorkshire fog (Holcus lanatus) [61], Camelina (Camelina sativa) [62], 
rubber tree (Hevea brasiliensis) [63], and cabbage (Brassica oleracea) [31], etc. Interestingly, TaALMT1 also plays a role in alkaline tolerance by promoting exudation of both malate and gamma-aminobutyric acid (GABA) in wheat. In addition, MATEs, which are well characterized as multidrug transporters, can transport various substrates, such as citrate, secondary metabolites, and plant hormones, through electrochemical cation gradients [64]. In recent years, MATE genes have been identified from various plant species, including Arabidopsis [65], cabbage [66], Brachypodium distachyon [32], eucalyptus (Eucalyptus camaldulensis) [67], buckwheat (Fagopyrum esculentum) [68], soybean (Glycine max) [33,69,70], Rubiaceae (Psychotria rubra) [71], sorghum (Sorghum bicolor) [72], rice bean (Vigna umbellata) [73-76], maize [77,78], wheat [36], wild soybean (Glycine soja) [34], etc. The difference in cell location and Al-induced expression patterns of MATE transporters have been determined. For instance, FeMATE1 localized on the plasma membrane (PM), is specifically expressed in roots, whereas FeMATE2 located on the Golgi membrane, is expressed in both the roots and the leaves [68]. Al stress could induce PtrMATE1 expression in $12 \mathrm{~h}$, in contrast to the expression pattern of PtrMATE2, which occurred $24 \mathrm{~h}$ after $\mathrm{Al}^{3+}$ treatment [35]. VUMATE1 was expressed at $6 \mathrm{~h}$ after $\mathrm{Al}$ stress, whereas VUMATE2 was expressed at the early stage of $\mathrm{Al}$ stress $[73,76]$. However, most plants that adopt external exclusion need to protect the root tip from $\mathrm{Al}$ toxicity directly on the root surface and ensure the dynamic balance of plant essential nutrients [79]. Al is the most abundant metal element in the earth's crust; plants cannot alleviate all $\mathrm{Al}$ toxicity in acidic soil but can neutralize a portion around the root tip. Therefore, the first reaction of plants to $\mathrm{Al}$ toxicity is to prevent the $\mathrm{Al}^{3+}$ around the root tip from entering the root cells, which may be the main target of OAs [80].

The transmembrane transport of OAs depends on the driving force formed by the proton electrochemical gradient on both sides of the $\mathrm{PM}$, which provides continuous power for organic acid secretion [81,82]. Al stress increases the activity of $\mathrm{PM} \mathrm{H}^{+}$-ATPase and inhibits the expression of VHA- $a 2, V H A-a 3$, and vacuolar proton pump activity, and therefore increases the proton gradient on both sides of the PM and promotes OAs secretion by AtALMT1 and AtMATE [83]. Al stress reduces the entry of OAs into vacuoles by inhibiting vacuolar proton pump activity and activating the PM transport system, which secretes large amounts of intracellular OAs to the apoplast. While OAs secretion is blocked, vacuolar proton pump activity is activated, indicating that intracellular $\mathrm{Al}$ tolerance may be an alternative [83]. Additionally, it is known that OAs secretion depends on the maintenance of internal concentrations of OAs. Zhou et al. identified a cytosolic NADP-malic enzyme, GmME1, which was implicated in the organic acid pool and confers higher Al resistance by increasing internal malate and citrate concentrations and their external efflux [40]. Recently, Sun et al. found that the level of the MsCS transcript was higher in Al tolerant cultivar as compared with the $\mathrm{Al}$ sensitive cultivar and the activity of citrate synthase (CS) affected Al resistance through citrate concentration and exudation in alfalfa cultivar [43]. These results suggest that OAs secretion can be regulated through the activation of OA transporters, PM $\mathrm{H}^{+}$-ATPase activity, and improvement of the internal OAs pool.

In addition to the secretion of OAs, the release of phenols has been verified to have the capacity to detoxify $\mathrm{Al}$ through chelating $\mathrm{Al}^{3+}$ ions. For example, $\mathrm{Al}$ and silicon ( $\mathrm{Si}$ ) trigger the release of catechol, catechins, and quercetin by root tips, which could potentially detoxify $\mathrm{Al}$ [84]. Ma et al. also found that phenolic compounds were involved in coping with $\mathrm{Al}$ toxicity in the Chinese fir by comparative transcriptome [85]. Chen et al. reported the enhancement of polyphenolic metabolism as an adaptive response to $\mathrm{Al}$ stress in lettuce roots [86]. Recently, the findings of $\mathrm{Fu}$ et al. indicated that Al-polyphenol complexes improved $\mathrm{Al}$ resistance in tea plants [87]. Therefore, a comprehensive exploration of the roles of phenolic compounds under $\mathrm{Al}$ stress might be an ideal target for genetic engineering in the future.

The $\mathrm{CW}$ is the first barrier for plants to resist external stress and has been recognized as the major target of $\mathrm{Al}$ toxicity; plants can alleviate $\mathrm{Al}$ stress by modifying the $\mathrm{CW}$ [88]. For example, OsSTAR1 interacts with OsSTAR2 to form an ATP-binding cassette (ABC) transporter complex, which is specifically responsible for transporting uridine diphosphate 
(UDP)-glucose and modifying CWs in rice [89]. Similarly, FeSTAR1 and FeSTAR2 also form an $\mathrm{ABC}$ transporter complex, which participates in $\mathrm{Al}$ tolerance through the $\mathrm{CW}$ matrix polysaccharide metabolism in buckwheat $[37,90]$. Recently, Fan et al. showed that abscisic acid (ABA) alleviation of Al toxicity in rice beans depends on ABI5-mediated CW modification and osmoregulation [91]. More recently, Liu et al. identified a 4-coumarate, which influences $\mathrm{Al}$ resistance through the modification the CW [46]. Moreover, pectin methylesterase (PME) plays an important role in $\mathrm{Al}$ tolerance by regulating the degree of pectin esterification in the $\mathrm{CW}$, which converts highly methylated pectin into a negatively charged demethylation form, resulting in more $\mathrm{Al}^{3+}$ binding to pectin [92]. Overexpression of OsPME14 accumulated the content of $\mathrm{Al}$ in the root tip CW and increased its sensitivity to $\mathrm{Al}$ in rice [93]. Furthermore, it was found that Al-tolerant varieties showed higher methylated pectin ratio and lower PME activity in rice, corn, and buckwheat $[13,94,95]$. Therefore, Al-resistant crop varieties can be cultivated by reducing the pectin content of plant root tips or increasing the degree of methylation of pectin.

Additionally, rhizosphere alkalization is one of $\mathrm{Al}$ tolerance mechanisms by reducing the solubility of $\mathrm{Al}$ [96]. For example, Yang et al. showed that elevated $\mathrm{pH}$ from 2.5 to 4.0, alleviates the Al-toxicity of Citrus by increasing root accumulation of malate and citrate $[97,98]$. Further experiment showed that raised $\mathrm{pH}$ alleviates Al-induced a decrease in total soluble protein level and an increase in electrolyte leakage in citrus leaves and roots by conferring the ability to maintain a balance between production and detoxification of ROS and methylglyoxal [92]. Moreover, Liu et al.'s study on wild barley showed that low $\mathrm{pH}$ and higher Al tolerance in XZ16 were associated with a higher ability of $\mathrm{H}^{+}$uptake and rhizospheric alkalization [99]. Magnesium promotes the elevated root surface $\mathrm{pH}$ regulation in Populus, resulting in root surface alkalization in the transition zone, which alleviates the toxicity of high concentration $\mathrm{Al}[100]$.

\subsection{Internal Tolerance Mechanisms}

Internal tolerance mechanisms are mainly involved in Al detoxification, uptake, translocation, and accumulation of non-phytotoxic complexes of $\mathrm{Al}$ in the various organs $[101,102]$. For instance, buckwheat, hydrangea, and tea can accumulate a large amount of $\mathrm{Al}$ in the aboveground parts via transporting nontoxic Al complexes [103-105]. Several transporters have been reported to be involved in the absorption, sequestration, and transportation of $\mathrm{Al}$ from roots to aboveground parts in plants. In rice, OsNrat1, a PM-located transporter, belongs to the natural resistance-associated macrophage protein (Nramp) and has low similarity with other Nramp members, which specifically transports $\mathrm{Al}^{3+}$ rather than bivalent metals $\left(\mathrm{Mn}^{2+}, \mathrm{Fe}^{2+}\right.$, and $\left.\mathrm{Cd}^{2+}\right)$ [102]. Bioinformatics suggest that the Ala-Ile-Ile-Thr element is the key determinant of Nrat1 for Al selectivity [106]. In Arabidopsis, AtALS3 acts as an Al transporter to redistribute Al outside sensitive tissues [107]. Moreover, OsALS1, an ABC transporter located in the tonoplast, sequestrates $\mathrm{Al}^{3+}$ in the vacuole. The knockout of OsALS1 leads the high sensitivity of rice to Al stress [26]. FeALS1.1 and FeALS1.2, OsALS1 homologs, can also sequestrate $\mathrm{Al}^{3+}$ in the vacuoles and detoxify $\mathrm{Al}$ in the roots and leaves in buckwheat [108]. Likewise, the AvABCG1 transporter confers $\mathrm{Al}$ tolerance by accumulating $\mathrm{Al}^{3+}$ in specific areas of Andropogon virginicus [109]. HvABCB25 transports $\mathrm{Al}$ from the cytoplasm to the vacuoles for sequestration in barley [42]. In addition, HmPALT1 and HmVALT1 are involved in transporting $\mathrm{Al}$ in hydrangea (Hydrangea macrophylla) [105]. The mechanism of Al detoxification in plants is achieved by forming non-phytotoxic complexes of small molecular organic compounds with $\mathrm{Al}^{3+}[10,27,52]$. NIP1;2, the closest homolog to HmPALT1, facilitates the transport of Al-malate from the CW to the symplast in Arabidopsis [110]. NIP1;2-mediated transport of Al-malate complex depends on Al-induced malate secretion mediated by AtALMT1. Therefore, the coordinated operation of the Al detoxification mechanism between external and internal parts of the plants is linked by NIP1;2 and AtALMT1.

Studies have showed that the transportation of other ions could also alleviate $\mathrm{Al}$ toxicity [19]. For example, $\mathrm{Ca}^{2+}$ serves as an essential second messenger to modulate 
developmental plasticity in plants, which reduces the concentration of active $\mathrm{Al}$ and fixation of $\mathrm{P}$ under $\mathrm{Al}$ stress [111,112]. Treatment with higher $\mathrm{Ca}^{2+}$ concentration alleviates Al-induced inhibition of root growth, which is attributed to higher cytosolic $\mathrm{Ca}^{2+}$ concentrations through specific $\mathrm{Ca}^{2+}$ signatures triggering downstream responses [113]. Moreover, $\mathrm{Mg}^{2+}$ is involved in metabolism-activating enzymes such as CS and malate synthase by functioning as a cofactor for enzymes, thereby activating OA synthesis to alleviate $\mathrm{Al}$ toxicity [114]. Overexpression of AtMGT1 and OsMGT1 confers Al tolerance in plants by increasing the absorption of $\mathrm{Mg}$ and inhibiting potential targets of $\mathrm{Al}$ [115]. Li et al. showed that $\mathrm{Mg}$ promoted root growth and increased $\mathrm{Al}$ tolerance by modulating the production of nitric oxide in Arabidopsis [116]. Similarly, Kong et al. showed that the addition of Mg to the $\mathrm{Al}$ treatment solution alleviated Al-induced inhibition of root growth, suppressed $\mathrm{Al}$ uptake, and reduced hydrogen peroxide $\left(\mathrm{H}_{2} \mathrm{O}_{2}\right)$ concentration in maize [99]. Furthermore, $\mathrm{K}^{+}$efflux was related to Al tolerance by accompanying OA secretion [99]. Recently, Li et al. showed that ectopic expression of either HtNHX1 or HtNHX2, from Jerusalem artichoke (Helianthus tuberosus), could enhance rice tolerance to $\mathrm{Al}$ stress and soil acidity by altering $\mathrm{K}^{+}$and $\mathrm{H}^{+}$fluxes and the $\mathrm{CW}$ structure [41]. In addition, the application of zinc has been shown to alleviate $\mathrm{Al}$-induced damage via competing with $\mathrm{Al}$ and increasing the IAA content in alfalfa [46]. Sulfate supplementation activates short-term tolerance to Al toxicity in perennial ryegrass (Lolium perenne) roots by upregulating total superoxide dismutase (SOD) activity [117]. Further studies are required to investigate how the adjustment of the formula of fertilizer may alleviate $\mathrm{Al}$ toxicity.

Analogous to other abiotic stimuli, Al stress induces the overproduction of ROS and lipid peroxidation, resulting in serious cell damage and even cell death [118]. To protect plants from Al-triggered oxidative stress, plant tolerance to Al toxicity is enhanced by improving the activity of ROS-scavenging enzymes, reducing the production of ROS, and weakening lipid peroxidation [119]. For example, overexpression of WMnSOD1, an Alinduced SOD, increases oxidative resistance, and $\mathrm{Al}$ tolerance [120]. Overexpression of $A t B C B$ and NtGDI1 ameliorates oxidative stress and confers a degree of resistance to $\mathrm{Al}$ stress [121]. Overexpression of AtPrx64 reduces the accumulation of ROS and $\mathrm{Al}$, thereby promoting root growth [29]. Recently, ZmAT6, a chloroplast-located protein, has been shown to increase the expression level of the $Z m S O D$ gene and improve the activity of antioxidant enzymes SOD in the antioxidant enzymatic system. In addition, the overexpression of ZmAT6 in maize and Arabidopsis increased the activity of several enzymes within the antioxidant system, thereby enhancing $\mathrm{Al}$ toxicity tolerance [50]. Moreover, methyltransferase could reduce ROS, lipid peroxidation, and ion leakage, and overexpression of the methyltransferase gene can improve stress resistance of plants [122]. For example, overexpression of $\mathrm{ZjOMT}$ enhanced $\mathrm{Al}$ tolerance of Escherichia coli by increasing the content of melatonin [49]. In addition, a metabolic change is an internal tolerance mechanistic in response to $\mathrm{Al}$ stress [48]. Overexpression of $V u F D H$ increased Al tolerance, which is likely due to their decreased Al-induced formate production in tobacco (Nicotiana tabacum) [48]. Likewise, VuAAE3 played a critical role in $\mathrm{Al}$ tolerance mechanisms via function as oxalyl-CoA synthetase [47].

\section{Transcription Factors Are Involved in Adaptation to Al Stress}

Transcription factors are protein complexes that regulate the transcription of genetic information from DNA to mRNA via specific binding to cis-acting elements in the promoters of target genes and acting downstream of signaling cascades in response to environmental stress [123]. The role of TFs in the Al signaling pathway has attracted significant attention since the first TF, sensitive to proton rhizotoxicity 1 (STOP1) and involved in Al tolerance, was identified. More TFs have also been identified to be involved in Al-induced signaling pathways (Table 2). 
Table 2. Transcription factors involved in $\mathrm{Al}$ tolerance.

\begin{tabular}{|c|c|c|c|c|}
\hline TFs & Categories & Plant Species & Functions & References \\
\hline $\begin{array}{l}\text { AtHB7 } \\
\text { AtHB12 }\end{array}$ & $\begin{array}{l}\text { HD-Zip I transcription } \\
\text { factor }\end{array}$ & $\begin{array}{l}\text { Arabidopsis thaliana } \\
\text { Arabidopsis thaliana }\end{array}$ & Regulate the capacity of the cell wall to bind $\mathrm{Al}$ & $\begin{array}{l}{[124]} \\
{[124]}\end{array}$ \\
\hline AtWRKY47 & WRKY transcription factor & Arabidopsis thaliana & $\begin{array}{l}\text { Regulating genes responsible for cell wall } \\
\text { modification }\end{array}$ & [125] \\
\hline OsWRKY22 & & Oryza sativa & $\begin{array}{l}\text { Activation of OsFRDL4 expression and } \\
\text { enhancement of citrate secretion }\end{array}$ & [126] \\
\hline CcSTOP1 & & Cajanus cajan & Regulate genes for OA transporters & [127] \\
\hline GhSTOP1 & & Gossypium hirsutum L. & Regulate GhMATE and GhALMT1 expression & [128] \\
\hline GmSTOP1a & & Glycine $\max$ & Regulate the downstream $\mathrm{Al}$ or & [129] \\
\hline GsGIS3 & $\begin{array}{l}\text { C2H2-type zinc finger } \\
\text { transcription factor }\end{array}$ & Glycine soja & $\begin{array}{l}\text { low } \mathrm{pH} \text { resistance genes } \\
\text { Regulating Al-tolerance-related genes }\end{array}$ & [130] \\
\hline HvATF1 & & Hordeum vulgare L. & $\begin{array}{l}\text { Regulating multiple downstream genes } \\
\text { involved in } \mathrm{Al} \text { resistance }\end{array}$ & [131] \\
\hline NtSTOP1 & & Nicotiana tabacum & Activation of NtMATE expression & [132] \\
\hline OsART2 & & Oryza sativa & $\begin{array}{l}\text { Regulate at least four genes implicated in } \mathrm{Al} \\
\text { tolerance }\end{array}$ & {$[133]$} \\
\hline SbSTOP1 & & Sorghum bicolor $\mathrm{L}$. & Regulate SbMATE and SbSTAR2 expression & [134] \\
\hline GsMAS1 & $\begin{array}{l}\text { MADS-box transcription } \\
\text { factor }\end{array}$ & Glycine Soja & $\begin{array}{l}\text { Accumulation of Al-activated citrate } \\
\text { and malate }\end{array}$ & [135] \\
\hline HvHOX9 & $\begin{array}{l}\text { Homeobox-leucine zipper } \\
\text { transcription factor }\end{array}$ & Hordeum vulgare $\mathrm{L}$. & Regulate the capacity of the cell wall to bind $\mathrm{Al}$ & [136] \\
\hline MdMYC2 & bHLH transcription factor & Malus domestica & Activation of ethylene biosynthesis & [137] \\
\hline VuABI5 & $\begin{array}{l}\text { Basic-leucine zipper } \\
\text { transcription factor }\end{array}$ & Vigna umbellata & $\begin{array}{l}\text { Regulate genes involved cell wall modification } \\
\text { and osmoregulation }\end{array}$ & [91] \\
\hline VuNAR1 & $\begin{array}{l}\text { NAC-type transcription } \\
\text { factor }\end{array}$ & Vigna umbellata & Regulate cell wall pectin metabolism & [138] \\
\hline
\end{tabular}

AtSTOP1, a C2H2-type zinc finger transcription factor, has been found to be critical for both proton and $\mathrm{Al}$ tolerance, which regulates the expression of downstream-STOP1 Alresistance genes (Figure 2). However, the expression of AtSTOP1 is unaffected by Al stress, which suggests that AtSTOP1 is modulated by $\mathrm{Al}$ at posttranscriptional or posttranslational levels. Zhang et al. showed that an F-box protein-encoding gene regulation of the $\mathrm{Al}$ activated malate transporter expression 1 (RAE1) regulates the stability of STOP1 via the ubiquitin-26S proteasome pathway in Arabidopsis. This indicates that STOP1 is regulated at a posttranslational level [139]. Recently, Guo et al. showed that hyperrecombination protein 1 (HPR1) regulates nucleocytoplasmic STOP1 mRNA export to modulate the expression of STOP1 downstream genes and $\mathrm{Al}$ resistance of plants, highlighting that the regulation of STOP1 by HPR1 occurs at a posttranscriptional level [140]. More recently, Fang et al. showed that the SUMOylation of STOP1 is involved in the regulation of Al resistance [141]. In this study, STOP1 is mono-SUMOylated at K40, K212, or K395 sites; and blocking STOP1 SUMOylation reduced $\mathrm{Al}$ resistance through the reduction in STOP1 stability and the expression of STOP1-regulated genes. Moreover, the SUMO protease ESD4 specifically interacts with deSUMOylates STOP1, and mutation of ESD4 increases the SUMOylation of STOP1 and the expression of AtALMT1, which contribute to Al stress tolerance. 


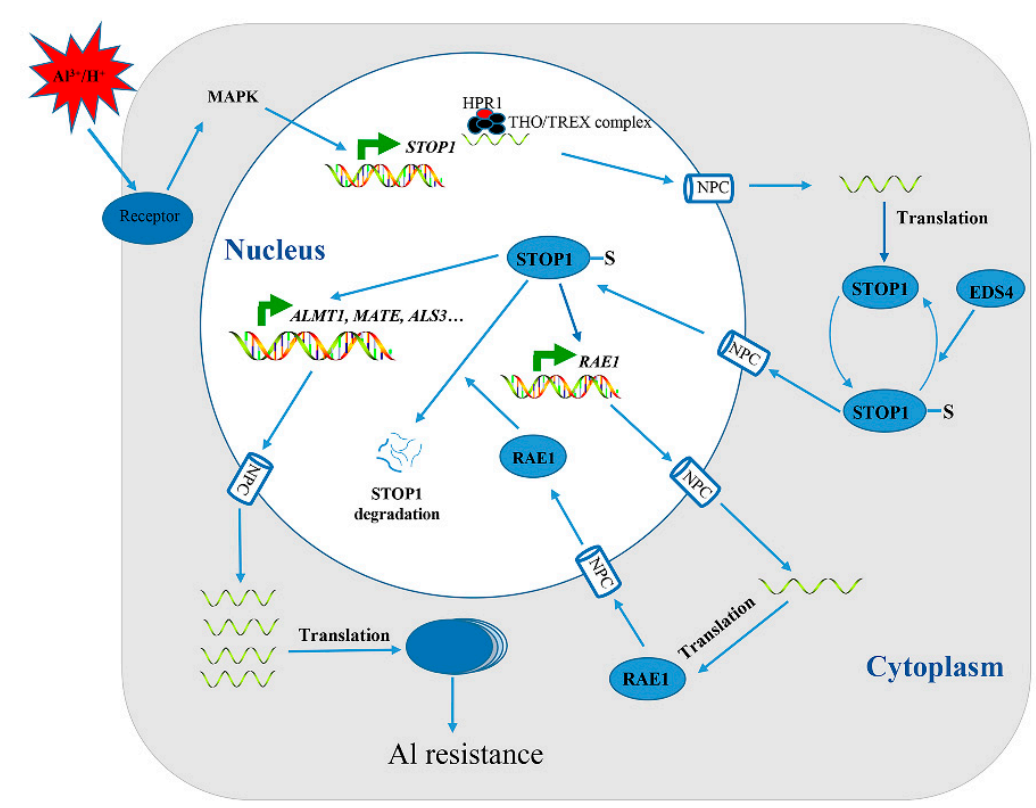

Figure 2. Model for regulation of STOP1 function and stability. RAE1, F-box protein-encoding gene regulation of AtALMT1 expression 1; HPR1, hyperrecombination protein 1; ESD4, SUMO protease; NPC, nuclear pore complex; STOP1-S, STOP1 SUMOylation.

The functions of STOP1-like proteins, including CcSTOP1 [127], GhSTOP1 [128], GmSTOP1 [129], NtSTOP1 [132], and SbSTOP1 [134], in other plant species, have been characterized, and proven to be essential for the expression of several Al-tolerance-related genes. For example, GmSTOP1 contributes to both $\mathrm{Al}$ resistance and $\mathrm{H}^{+}$tolerance, and overexpression of GmSTOP1a increases the expression of GmALMT1 and decreases Al accumulation in soybean hairy roots under Al stress [129]. AtSTOP1 and OsART1 are both central regulators involved in $\mathrm{Al}$ tolerance through the regulation of multiple downstream genes. However, the rice homolog ( $\mathrm{Al}$ resistance transcription factor, OsART1) regulates only Al tolerance genes [142]. Furthermore, OsART2, a homolog of OsART1, has been shown to regulate $\mathrm{Al}$ tolerance independent of the OsART1-regulated pathway in rice and to play a supplementary role in Al tolerance [133]. HvATF1 (Al-tolerant transcription factor 1) is the closest homolog of AtSTOP1 and OsART1 and alleviates Al stress through regulating multiple genes in barley; this provides insights into the different molecular mechanisms of $\mathrm{Al}$ tolerance in plants [131]. Liu et al. also cloned a $\mathrm{C} 2 \mathrm{H} 2$ zinc-finger protein, GsGIS3, which enhanced tolerance to $\mathrm{Al}$ toxicity by regulating Al-tolerance-related genes [130].

In Arabidopsis, two HD-Zip I TFs (AtHB7 and AtHB12) have been identified to specifically participate in $\mathrm{Al}$ resistance through a reversed genetic approach. Interestingly, AtHB7 and AtHB12 promote root growth through positive regulation of the cell number and cell length under normal conditions, while playing opposite roles by regulating the capacity of the $\mathrm{CW}$ to bind $\mathrm{Al}^{3+}$ under Al stress [124]. Recently, HvHOX9, a novel homeobox-leucine zipper transcription factor, was identified to play a critical role in $\mathrm{Al}$ tolerance in barley by decreasing root $\mathrm{CW} \mathrm{Al}$ binding, increasing apoplastic $\mathrm{pH}$ in the root, and silencing of $\mathrm{HvHOX} 9$ which increased $\mathrm{Al}$ accumulation in root $\mathrm{CW}$ and decreased $\mathrm{H}^{+}$influx after $\mathrm{Al}$ exposure [136]. Li et al. showed that WRKY47 was involved in altering Al distribution between the apoplast and symplast by regulating the genes responsible for $\mathrm{CW}$ modification, thereby improving Al tolerance [125]. Lou et al. reported that a NAC-type TF, VuNAR1, is involved in $\mathrm{Al}$ resistance in rice beans, and overexpression of VuNAR1 induced higher WAK1 expression and low pectin content via directly binding to the WAK1 promoter and regulating CW pectin metabolism [138]. Li et al. demonstrated that OsWRKY22 contributes to $\mathrm{Al}$ tolerance by functioning together with OsART1 in the positive regulation of OsFRDL4 expression and citrate secretion [126]. A MADS-box transcription factor, GsMAS1, presents 
a constitutive expression pattern induced under Al stress. The overexpression of GsMAS1 enhanced the tolerance to Al stress in Arabidopsis with larger values of the relative root length and higher proline accumulation as compared with those of wild type (WT) under Al stress through Al stress-related pathways [135]. These findings emphasize the need to study transcription factors involved in Al tolerance, which could help to understand the entire molecular network of Al tolerance in plants, elucidate the mechanism of plant $\mathrm{Al}$ tolerance, and lay a theoretical foundation for the cultivation of Al-tolerant varieties using modern molecular techniques.

\section{Plant Hormones Involved in Adaptation to Al Stress}

Plant hormones play an important role in the internal tolerance mechanisms $[23,143]$. For example, TAA1 regulates auxin biosynthesis in the root apex transition zone (TZ) in Arabidopsis, which mediates Al-induced inhibition of root elongation [144]. Subsequently, flavin monooxygenase-like proteins (YUCCA), which act downstream of TAA1, have been reported; they regulate auxin accumulation in the root apex $\mathrm{TZ}$ in response to $\mathrm{Al}$ stress, thereby controlling root growth $[145,146]$. The synergistic effect of auxin and cytokinin in response to Al stress in Arabidopsis has been described; Al stress induces the expression of the key gene of cytokinin synthesis by mediating Al-induced auxin signaling, eventually leading to the accumulation of cytokinin and inhibiting root growth in the root apex TZ [147]. Moreover, miR393 is involved in Al-induced root growth inhibition by regulating auxin signaling in barley [148]. Exogenous IAA treatment could promote the secretion of $\mathrm{H}^{+}$in the plant rhizosphere, balance the level of $\mathrm{H}^{+}$in internal and external cells, and reduce $\mathrm{Al}$ content in pectin by reducing the content of pectin and PME activity in the root tip. This reduces Al accumulation in the CW $[149,150]$. Wang et al. investigated an auxin influx carrier, OsAUX3, which is involved in root growth in response to Al stress by affecting acropetal auxin transport in rice [46]. Similarly, Zhang et al. found that an auxin efflux carrier, ZmPGP1, was involved in root growth inhibition in maize under $\mathrm{Al}$ stress [44]. The Al tolerance of OsAUX3 knockdown lines and zmpgp1 mutants was significantly higher than that of WT but auxin accumulation had an opposite trend in root tips. These findings show that auxin may play different roles in Al-induced root growth inhibition in different plants.

Melatonin is universally distributed in plants, and it plays important roles in various physiological and biochemical processes [151]. Recent studies have shown that melatonin ameliorates Al toxicity by scavenging ROS and secreting OAs. For example, melatonin enhanced the activities of antioxidant enzymes and increased the exudation of malate and citrate in soybean [152]. Moreover, melatonin interferes with nitric oxide (NO)-mediated reduction in cell division cycle progression and the quiescent center cellular activity, which subsequently alleviates Al-induced root growth inhibition [153]. Furthermore, melatonin confers $\mathrm{Al}$ tolerance by decreasing $\mathrm{Al}$ binding in the CWs. In wheat seedlings, melatonin augments antioxidants and induces antioxidant enzymes to control ROS and also enhances the exclusion of Al from the root apex by altering CW polysaccharides [154]. Therefore, melatonin ameliorates $\mathrm{Al}$ toxicity by building a defense line in response to $\mathrm{Al}$ stress, which suggests that applying exogenous melatonin or enhancing melatonin biosynthesis may be an effective strategy for enhanceing plant Al resistance.

Ethylene mediated Al-induced inhibition of root growth has also been confirmed using mutants defective in ethylene signaling [155]. An et al. found that MdMYC2 negatively regulates $\mathrm{Al}$ tolerance through upregulating the expression of ethylene-responsive genes by binding to the promoter of $M d E R F 3$ (positive regulator of ethylene biosynthesis) [137]. The synergistic action of auxin and ethylene mediates Al-induced inhibition of root growth [143,155]. Moreover, Chen et al. showed that GmGRPL conferred Al tolerance in Arabidopsis through regulation of the level of IAA and ethylene and improvement of antioxidant activity [38]. Similarly, overexpression of the GsERF gene enhanced Al tolerance of Arabidopsis through an ethylene-mediated pathway [156]. In addition, ABA was involved in regulating Al tolerance [157]. For example, ABA was involved in the early tol- 
erance mechanism in buckwheat seedlings by increasing the levels of ROS and activities of catalase (CAT) and ascorbate peroxidase (APX) [158]. Recently, Fan et al. showed that ABA alleviation of $\mathrm{Al}$ toxicity in rice beans depends on $\mathrm{ABI} 5$-mediated $\mathrm{CW}$ modification and osmoregulation [91]. These findings indicate that plants respond to Al stress by regulating the distribution and levels of various plant hormones.

\section{Small Molecules to Alleviate Al Toxicity}

Al toxicity is a major limiting abiotic factor for plant growth and productivity in acidic soils. In the past few decades, various strategies have been used to alleviate Al toxicity. Interestingly, the use of small molecules to alleviate Al toxicity has been confirmed. Among these, there are many reports about $\mathrm{Si}$, boron (B), and polyamines (PA).

Silicon is the second most abundant element in the earth's crust after oxygen and has versatile functions in plant biology, especially in plant defense and tolerance to both biotic and abiotic stressors [159]. Si ameliorates the effects on Al toxicity in maize [160], Norway spruce [161], rice [106,162,163], ryegrass [164], soybean [94], sorghum [165], and wheat [166]. For example, Si treatment was shown to increase the growth of plant shoots grown in the presence of Al without influencing the root growth in upland rice [163]. In ryegrass, Si-mediate the alleviation of $\mathrm{Al}$ toxicity by the modulation of $\mathrm{Al} / \mathrm{Si}$ uptake and antioxidant performance [164]. In soybean and sorghum, Si reduces Al toxicity through the formation of Al-Si complexes in mucigel and outer cellular tissues, thereby decreasing the binding of Al to the CW [165]. These results suggest that the alleviation of Al toxicity by $\mathrm{Si}$ is an effective strategy of $\mathrm{Al}$ detoxification for improving plant tolerance in acid soils.

Boron is an essential microelement for plant growth and is involved in alleviating Al toxicity. This has been identified in many plant species, including citrus [167-169], common bean [170], pea [171-173], rapeseed [174], sunflower [175], and wheat [176]. Li et al. reported that pretreatment with $\mathrm{B}$ promoted polar auxin transport driven by the auxin efflux transporter, PIN2, led to the downstream regulation of the PM- $\mathrm{H}^{+}$-ATPase, resulting in elevated root surface $\mathrm{pH}$, which is essential to decrease $\mathrm{Al}$ accumulation in this Al-targeted apical root zone [173]. Moreover, pretreatment with B significantly increased the activity of APX, peroxidase (POD), and CAT, therefore, increasing the elimination rate of $\mathrm{H}_{2} \mathrm{O}_{2}$ in rice roots [177]. Furthermore, Yan et al. revealed that $\mathrm{B}$ pretreatment improved root growth by weakening $\mathrm{Al}$ binding to alkali-soluble pectin, and reduced $\mathrm{Al}$ fixation on the $\mathrm{CW}$ reduced $\mathrm{Al}$ accumulation, resulting in the alleviation of $\mathrm{Al}$ toxicity [178]. Therefore, the application of B in nutrient solutions significantly increases root growth by alleviating Al toxicity, emphasizing the feasibility of this method.

Polyamines are important signaling molecules in the ROS regulation under Al stress. The application of putrescine could protect plant roots against Al-induced oxidative stress by maintaining the antioxidant capacity in wheat $[179,180]$. Putrescine could reduce the $\mathrm{Al}$ content in the $\mathrm{CW}$ by inhibiting the production of ethylene, therefore, alleviating the inhibition of the root growth in wheat and rice [181,182]. Likewise, the application of spermidine alleviates the adverse effects of Al toxicity by improving the antioxidant system, as has been demonstrated in rice and mung bean $[183,184]$. These findings show that the application of polyamines or improvement of endogenous polyamine content is an effective strategy for plants to adapt to acidic soil.

$\mathrm{P}, \mathrm{OAs}$, biochar, etc. reduce the effect of $\mathrm{Al}$ toxicity. The addition of $\mathrm{P}$ relieves $\mathrm{Al}$ toxicity by increasing the carbohydrate content and relieving the inhibition of protein synthesis [185]. The application of malate has also been shown to alleviate Al toxicity in Pinus massoniana seedlings [186]. The application of biochar increases the $\mathrm{pH}$ value, water holding capacity, and available nutrients in acidic soil, and also improves soil texture and aggregation, therefore, relieving the plants [187]. Lin et al. showed that biochar alleviates Al toxicity in achieving cabbage productivity [188]. Xia et al. reported that biochar mitigates the Al toxicity of maize, which contributes to the improvement of soil quality and enhancement of nitrogen use efficiency in acidic soil [189]. These results show that the ability of small molecules to alleviate Al toxicity is a strategy in the acidic 
soil. However, further studies are needed to ascertain promising and sustainable small molecules for ameliorating $\mathrm{Al}$ toxicity.

\section{Plant Growth-Promoting Rhizobacteria (PGPRs) Alleviate Al Toxicity}

Plant growth-promoting rhizobacteria are known to exert beneficial effects on plant growth and health $[190,191]$. Several studies have reported the application of PGPR mitigated $\mathrm{Al}$ toxicity in acidic soil (Table 3). For example, inoculation with Pseudomonas fluorescens 002 decreased the impact of $\mathrm{Al}$ toxicity in maize roots and increased the root lengths and numbers [192]. Similarly, P. plecoglossicida Pp20 conferred maize root tolerance to $\mathrm{Al}$ toxicity by producing the enzyme 1-aminocyclopropane-1-carboxylate (ACC) deaminase and IAA [193]. The authors further reported that Bacillus toyonensis Bt04 reduced $\mathrm{Al}$ accumulation and lipid peroxidation in maize seedlings, promoted maize growth, and enhanced root development [194]. Moreover, inoculation of B. megaterium CAM12 and Pantoea agglomerans CAH6 improves Vigna radiata growth and reduces Al uptake in plants [195]. The subsequent experiment revealed that Rhodotorula mucilaginosa CAM4 reduced $\mathrm{Al}$ accumulation and conferred $\mathrm{Al}$ tolerance to Lactuca sativa [196]. Furthermore, Al-resistant PGPR induced a higher expression level of Al-stress related genes, exudation of OAs, and production of polysaccharides, thereby alleviating Al toxicity [197-199]. Additionally, Rhizobium panacihumi DCY $116^{\mathrm{T}}$ was used as a potential PGPR, which produced higher proline, phenolic, sugar contents, and related gene expressions, to induce ROS scavenging activity in Al-stressed seedlings [200]. These studies support the application of PGPR to improve plant growth in acidic soils, by functioning as a biofertilizer for healthy and safe crop production.

Table 3. Plant growth-promoting rhizobacteria (PGPRs) alleviate Al toxicity.

\begin{tabular}{|c|c|c|c|c|}
\hline Strains & Function & Target Plant & $\begin{array}{c}\text { Effect of Aluminum Imposed on } \\
\text { Plant }\end{array}$ & References \\
\hline $\begin{array}{l}\text { Bacillus megaterium } \\
\text { CAM12 }\end{array}$ & Produce siderophore & Vigna radiata & Reduced Al uptake & [195] \\
\hline Bacillus sp. PSB16 & $\begin{array}{l}\text { Produce OAs and } \\
\text { polysaccharides }\end{array}$ & Oryza sativa & $\begin{array}{c}\text { Chelated the } \mathrm{Al} \text {, increased solution } \\
\mathrm{pH} \text {, and enhanced rice growth } \\
\text { Reduced } \mathrm{Al} \text { accumulation in the }\end{array}$ & [197] \\
\hline Bacillus toyonensis $\mathrm{Bt} 04$ & $\begin{array}{l}\text { Produce auxin and } \\
\text { cytokinin }\end{array}$ & Zea mays & $\begin{array}{c}\text { young maize roots, promotes maize } \\
\text { growth, and enhances root } \\
\text { development }\end{array}$ & [194] \\
\hline $\begin{array}{c}\text { Burkholderia } \\
\text { ginsengiterrae } \mathrm{N} 11-2\end{array}$ & $\begin{array}{l}\text { Produce auxins and } \\
\text { siderophores and } \\
\text { phosphate } \\
\text { solubilization }\end{array}$ & $\begin{array}{l}\text { Arabidopsis thaliana } \\
\text { and Panax ginseng }\end{array}$ & $\begin{array}{c}\text { Showed the higher expression level } \\
\text { of Al-stress related genes and higher } \\
\text { biomass and higher chlorophyll } \\
\text { content }\end{array}$ & [198] \\
\hline $\begin{array}{l}\text { Burkholderia seminalis } \\
\text { ASB21 }\end{array}$ & $\begin{array}{l}\text { Produce OAs and } \\
\text { polysaccharides }\end{array}$ & Oryza sativa & $\begin{array}{l}\text { Chelated the } \mathrm{Al} \text {, increased solution } \\
\mathrm{pH} \text {, and enhanced rice growth }\end{array}$ & [197] \\
\hline $\begin{array}{c}\text { Burkholderia } \\
\text { thailandensis ASB7 }\end{array}$ & $\begin{array}{l}\text { Produce OAs and } \\
\text { polysaccharides }\end{array}$ & Oryza sativa & $\begin{array}{l}\text { Chelated the } \mathrm{Al} \text {, increased solution } \\
\mathrm{pH} \text {, and enhanced rice growth }\end{array}$ & [197] \\
\hline $\begin{array}{l}\text { Chryseobacterium } \\
\text { polytrichastri N10 }\end{array}$ & $\begin{array}{l}\text { Produce auxins and } \\
\text { siderophores and } \\
\text { phosphate } \\
\text { solubilization }\end{array}$ & $\begin{array}{l}\text { Arabidopsis thaliana } \\
\text { and Panax ginseng }\end{array}$ & $\begin{array}{c}\text { Showed the higher expression level } \\
\text { of Al-stress related genes and higher } \\
\text { biomass and higher chlorophyll } \\
\text { content }\end{array}$ & [198] \\
\hline Enterobacter sp. RJAL6 & $\begin{array}{l}\text { Secrete oxalate, citrate, } \\
\text { succinate and } \\
\text { siderophores }\end{array}$ & Lolium perenne & $\begin{array}{l}\text { Promote ryegrass growth by } \\
\text { forming Al-siderophore complexes }\end{array}$ & [199] \\
\hline Klebsiella sp. RC3 & $\begin{array}{l}\text { Secrete oxalate, malate, } \\
\text { citrate, succinate and } \\
\text { siderophores }\end{array}$ & Lolium perenne & $\begin{array}{l}\text { Promote ryegrass growth by } \\
\text { forming Al-siderophore complexes }\end{array}$ & [199] \\
\hline Klebsiella sp. RCJ4 & $\begin{array}{l}\text { Secrete malate, citrate, } \\
\text { succinate and } \\
\text { siderophores }\end{array}$ & Lolium perenne & $\begin{array}{l}\text { Promote ryegrass growth by } \\
\text { forming Al-siderophore complexes }\end{array}$ & [199] \\
\hline
\end{tabular}


Table 3. Cont.

\begin{tabular}{|c|c|c|c|c|}
\hline Strains & Function & Target Plant & $\begin{array}{l}\text { Effect of Aluminum Imposed on } \\
\text { Plant }\end{array}$ & References \\
\hline $\begin{array}{c}\text { Pantoea agglomerans } \\
\text { CAH6 }\end{array}$ & Produce siderophore & Vigna radiata & Reduced Al uptake & [195] \\
\hline Pseudomonas fragi N8 & $\begin{array}{l}\text { Produce auxins and } \\
\text { siderophores and } \\
\text { phosphate } \\
\text { solubilization }\end{array}$ & $\begin{array}{l}\text { Arabidopsis thaliana } \\
\text { and Panax ginseng }\end{array}$ & $\begin{array}{l}\text { Showed the higher expression level } \\
\text { of Al-stress related genes and higher } \\
\text { biomass and higher chlorophyll } \\
\text { content }\end{array}$ & [198] \\
\hline $\begin{array}{c}\text { Pseudomonas } \\
\text { plecoglossicida Pp20 }\end{array}$ & $\begin{array}{c}\text { Produce ACC } \\
\text { deaminase and IAA }\end{array}$ & Zea mays & $\begin{array}{l}\text { Increased in lengths of seminal roots } \\
\text { and root dry mass }\end{array}$ & [193] \\
\hline Pseudomonas simiae N3 & $\begin{array}{l}\text { Produce auxins and } \\
\text { siderophores and } \\
\text { phosphate } \\
\text { solubilization }\end{array}$ & $\begin{array}{l}\text { Arabidopsis thaliana } \\
\text { and Panax ginseng }\end{array}$ & $\begin{array}{c}\text { Showed the higher expression level } \\
\text { of Al-stress related genes and higher } \\
\text { biomass and higher chlorophyll } \\
\text { content }\end{array}$ & [198] \\
\hline $\begin{array}{l}\text { Stenotrophomonas } \\
\text { maltophilla } \mathrm{Sb} 16\end{array}$ & $\begin{array}{l}\text { Produce OAs and } \\
\text { polysaccharides }\end{array}$ & Oryza sativa & $\begin{array}{l}\text { Chelated the } \mathrm{Al} \text {, increased solution } \\
\mathrm{pH} \text {, and enhanced rice growth }\end{array}$ & {$[197]$} \\
\hline $\begin{array}{l}\text { Pseudomonas } \\
\text { fluorescens } 002\end{array}$ & Releases IAA & Zea mays & $\begin{array}{c}\text { increased primary, lateral, and } \\
\text { seminal root lengths and numbers, } \\
\text { as well as root dry mass }\end{array}$ & {$[182]$} \\
\hline $\begin{array}{c}\text { Rhodotorula } \\
\text { mucilaginosa CAM4 }\end{array}$ & Bioaccumulation of $\mathrm{Al}$ & Lactuca sativa & $\begin{array}{l}\text { Reduce proline and MDA contents, } \\
\text { and enhance accumulation of } \\
\text { antioxidant enzymes }\end{array}$ & [196] \\
\hline $\begin{array}{l}\text { Rhizobium panacihumi } \\
\text { DCY116 } 11\end{array}$ & Produce IAA & Panax ginseng & $\begin{array}{c}\text { Produced higher proline, phenolic, } \\
\text { sugar contents and related gene } \\
\text { expressions to induce ROS } \\
\text { scavenging activity }\end{array}$ & {$[200]$} \\
\hline $\begin{array}{l}\text { Stenotrophomonas sp. } \\
\text { RC5, }\end{array}$ & $\begin{array}{l}\text { Secrete malate, citrate, } \\
\text { succinate and } \\
\text { siderophores }\end{array}$ & Lolium perenne & $\begin{array}{l}\text { Promote ryegrass growth by } \\
\text { forming Al-siderophore complexes }\end{array}$ & [199] \\
\hline Serratia sp. RCJ6 & $\begin{array}{l}\text { Secrete malate, citrate } \\
\text { and } \\
\text { succinate }\end{array}$ & Lolium perenne & $\begin{array}{l}\text { Promote ryegrass growth by } \\
\text { forming Al-siderophore complexes }\end{array}$ & [199] \\
\hline
\end{tabular}

\section{Transgenic Approaches Manipulating Al-Tolerant Genes}

Transgenic breeding is a promising tool for abiotic stress improvement in crops, which can create new and significant sources of resistance with rapid multiplication potentials [201]. In the previous decade, numerous studies were conducted to develop Al-tolerant crop cultivars through the manipulation of Al-tolerant genes, mainly concentrating on the secretion of OAs, Al sequestration, and defense system.

$\mathrm{Al}$-induced OAs secretion is an important mechanism for controlling the degree of resistance to $\mathrm{Al}$ toxicity in most plant species $[5,17,27]$. Therefore, increasing OAs secretion is a research hotspot in the cultivation of Al-tolerant plant varieties. However, this is mainly achieved through the genetic transformation of enzymes related to OAs metabolism and OAs channel proteins. To date, ALMT and MATE have been identified to confer Al tolerance through the secretion of malate and citrate. Particularly, heterologous expression of ALMT or MATE confers Al-induced malate or citrate secretion and enhances their Al tolerance in transgenic plants. For example, GmMATE13, GmMATE47, GmMATE75, GmMATE79, and GmMATE87 have a citrate transport activity; and overexpression of these genes have enhanced the tolerance of transgenic plants to Al toxicity in Arabidopsis [70,202]. Recently, AhFRDL1, a citrate transporter gene from peanut (Arachis hypogaea) that is induced by both iron (Fe)-deficiency and $\mathrm{Al}$ stress, participated in both root-to-shoot Fe translocation and $\mathrm{Al}$ tolerance. Overexpression of AhFRDL1 in Fe-efficient varieties contributed to higher levels of $\mathrm{Al}$ tolerance and Fe translocation by promoting citrate secretion [28]. Additionally, the secretion of OAs is related to the maintenance of internal concentrations of OAs and the activity of $\mathrm{PM} \mathrm{H}^{+}$-ATPase $[43,81]$. Therefore, the combined 
transformation of these multiple genes should be considered and explored for sustainable applications in the future.

The compartmentalization and detoxification of vacuoles is an important internal tolerance mechanism in plants $[131,203,204]$. Al transporters in the PM and tonoplast play an important role and the genetic transformation of these transporters can significantly improve the $\mathrm{Al}$ tolerance of plants. For example, overexpression of $H v A B C B 25$ significantly improves $\mathrm{Al}$ tolerance and reduces $\mathrm{Al}$ accumulation of root tip cytoplasm in Tibetan wild barley [42]. FeIREG1, an IREG transporter located in the tonoplast in buckwheat, plays an important role in detoxification by sequestrating $\mathrm{Al}$ into vacuoles. Overexpression of FeIREG1 enhances Al tolerance in Arabidopsis [203]. In soybean, the function of GmIREG3 is similar to that of FeIREG1, and overexpression of GmIREG3 enhances Al tolerance in Arabidopsis [39]. In rice, $\mathrm{Al}$ transporter OsNrat1 and OsALS1 cooperate to detoxify Al. Overexpression of OsNrat1 enhances Al tolerance in Arabidopsis [101]. In other plants, OsNrat1 homologous genes, including ZmNrat1 [205] and SbNrat1 [206], have also been reported to be involved in transporting $\mathrm{Al}$. To the best of our knowledge, the co-genetic transformation of $\mathrm{Al}$ transporters in the PM and tonoplast has not been reported. Hence, their transformation into Al-sensitive plants to enhance $\mathrm{Al}$ tolerance is necessary.

Plants improve stress resistance by regulating the expression of tolerant genes. The transformation of these genes can effectively improve Al tolerance of plants [201]. For example, AvSAMS1 is a multiple tolerance gene and transgenic Arabidopsis showed a higher tolerance to $\mathrm{Al}$ stress than Col-0 ecotype and also higher tolerance to other metal stresses [30]. In addition, the DNA damage response (DDR) pathway maintains the genome integrity under adverse conditions that affect DNA replication. The inhibition of root growth regulated by DDR regulators in response to $\mathrm{Al}$ toxicity pinpoints DNA as a primary target of internalized $\mathrm{Al}$ and also offers new strategies for obtaining Al-resistant crops. Due to the highly conserved nature and function of the DDR, identified Arabidopsis mutations may be easily mimicked in orthologous crop genes using the latest developments in the CRISPR/Cas9 field [4], which provides useful insight into the genetic basis for a new $\mathrm{Al}$ detoxification mechanism for improving plant tolerance to $\mathrm{Al}$ stress in acid soils.

\section{Conclusions and Future Perspectives}

$\mathrm{Al}$ stress is considered to be an important factor limiting plant growth in acidic soil, but other minerals present in the soil can interact with $\mathrm{Al}$ [10]. This review covers the current knowledge about $\mathrm{Al}$ resistance genes and the adaptive mechanisms of various crops under $\mathrm{Al}$ stress. However, studies investigating the effect of $\mathrm{Al}$ interactions with other restricting factors are scarce. These studies are imperative for developing plant varieties in acidic soils.

The sensing of $\mathrm{Al}$ stress by plants and the transduction of the $\mathrm{Al}$ signal to activate various downstream Al-tolerant strategies are fundamental frontier issues in plant sciences. Studies have shown that signaling cascades of Al-induced citrate exudation comprised heterotrimeric G-proteins, phospholipase $\mathrm{C}$, inositol triphosphate, diacylglycerol, $\mathrm{Ca}^{2+}$, and protein kinases $[2,6]$. However, there are limited reports on $\mathrm{Al}$ transmembrane signal transduction. The $\mathrm{Al}$ receptor has not yet been identified, which is the most important topic in plant $\mathrm{Al}$ stress research. Currently, salt and $\mathrm{H}_{2} \mathrm{O}_{2}$ sensors have been found using $\mathrm{Ca}^{2+}$ imaging-based forward genetic screens, which inspires the identification of $\mathrm{Al}$ receptor $[207,208]$. Future work should focus on the identification of early Al-sensing components using genetic and biochemical approaches.

The rapid development of whole-genome sequencing and genome editing technology provides more opportunities to reveal the mechanisms of Al tolerance and identify novel Al-tolerant genes, which make it possible to cultivate Al-tolerant plant varieties using modern biotechnology. Al tolerance in plants is a multi-level, multi-pathway, and multigene control process. However, the improvement of $\mathrm{Al}$ tolerance of transgenic plants is concentrated on one single gene. Therefore, the development of multiple Al tolerance 
genes is critical to enhancing the Al tolerance of plants in acidic soils through molecular and conventional breeding.

Author Contributions: Conceptualization, Y.W. and R.H.; Writing-Original Draft Preparation, Y.W. and Y.X.; Writing-Review and Editing, Y.W. and C.J.; Formal Analysis, Y.W. and C.J.; Funding Acquisition, Y.Y. All authors have read and agreed to the published version of the manuscript.

Funding: This study was funded by the National Key R\&D Program of China (no. 2018YFD0502000, State Cultivation Base of Eco-agriculture for Southwest Mountainous Land, Southwest University, 400715, Chongqing, China.

Institutional Review Board Statement: Not applicable.

Informed Consent Statement: Not applicable.

Data Availability Statement: No new data were created or analyzed in this study. Data sharing is not applicable to this article.

Conflicts of Interest: The authors declare no conflict of interest.

\section{References}

1. Zheng, S.J. Crop production on acidic soils: Overcoming aluminium toxicity and phosphorus deficiency. Ann. Bot. 2010, 106, 183-184. [CrossRef]

2. Wei, Y.; Jiang, C.; Han, R.; Xie, Y.; Liu, L.; Yu, Y. Plasma membrane proteomic analysis by TMT-PRM provides insight into mechanisms of aluminum resistance in tamba black soybean roots tips. PeerJ 2020, 8, e9312. [CrossRef]

3. Kochian, L.V.; Piñeros, M.A.; Liu, J.; Magalhaes, J.V. Plant Adaptation to Acid Soils: The Molecular Basis for Crop Aluminum Resistance. Annu. Rev. Plant Biol. 2015, 66, 571-598. [CrossRef]

4. Eekhout, T.; Larsen, P.; De Veylder, L. Modification of DNA Checkpoints to Confer Aluminum Tolerance. Trends Plant Sci. 2017, 22, 102-105. [CrossRef] [PubMed]

5. Yang, L.T.; Qi, Y.P.; Jiang, H.X.; Chen, L.S. Roles of organic acid anion secretion in aluminium tolerance of higher plants. BioMed Res. Int. 2013, 2013, 9-15. [CrossRef] [PubMed]

6. Jiang, C.; Liu, L.; Li, X.; Han, R.; Wei, Y.; Yu, Y. Insights into aluminum-tolerance pathways in Stylosanthes as revealed by RNA-Seq analysis. Sci. Rep. 2018, 8, 1-9. [CrossRef] [PubMed]

7. Huws, S.A.; Creevey, C.J.; Oyama, L.B.; Mizrahi, I.; Denman, S.E.; Popova, M.; Muñoz-Tamayo, R.; Forano, E.; Waters, S.M.; Hess, M.; et al. Addressing global ruminant agricultural challenges through understanding the rumen microbiome: Past, present, and future. Front. Microbiol. 2018, 9, 1-33. [CrossRef] [PubMed]

8. Snowden, K.C.; Cardner, R.C. Five genes induced by aluminum in wheat (Triticum aestivum L.) roots. Plant Physiol. 1993, 103, 855-861. [CrossRef]

9. Regisfer, P.G.; Richards, K.D.; Snowden, K.C.; Cardner, R.C. wali6 and wali7: Genes induced by aluminum in wheat (Triticum aestivum L.) roots. Plant Physiol. 1994, 105, 1455-1456.

10. Muhammad, N.; Zvobgo, G.; Zhang, G.P. A review: The beneficial effects and possible mechanisms of aluminum on plant growth in acidic soil. J. Integr. Agric. 2019, 18, 1518-1528. [CrossRef]

11. Wang, L.; Fan, X.W.; Pan, J.L.; Huang, Z.B.; Li, Y.Z. Physiological characterization of maize tolerance to low dose of aluminum, highlighted by promoted leaf growth. Planta 2015, 242, 1391-1403. [CrossRef] [PubMed]

12. Bais, H.P.; Weir, T.L.; Perry, L.G.; Gilroy, S.; Vivanco, J.M. The role of root exudates in rhizosphere interactions with plants and other organisms. Annu. Rev. Plant Biol. 2006, 57, 233-266. [CrossRef] [PubMed]

13. Eticha, D.; Stass, A.; Horst, W.J. Cell-wall pectin and its degree of methylation in the maize root-apex: Significance for genotypic differences in aluminium resistance. Plant Cell Environ. 2005, 28, 1410-1420. [CrossRef]

14. Singh, S.; Tripathi, D.K.; Singh, S.; Sharma, S.; Dubey, N.K.; Chauhan, D.K.; Vaculík, M. Toxicity of aluminium on various levels of plant cells and organism: A review. Environ. Exp. Bot. 2017, 137, 177-193. [CrossRef]

15. Wang, Y.; Yu, W.; Cao, Y.; Cai, Y.; Lyi, S.M.; Wu, W.; Kang, Y.; Liang, C.; Liu, J. An exclusion mechanism is epistatic to an internal detoxification mechanism in aluminum resistance in Arabidopsis. BMC Plant Biol. 2020, 20, 1-12. [CrossRef]

16. Riaz, M.; Yan, L.; Wu, X.; Hussain, S.; Aziz, O.; Jiang, C. Mechanisms of organic acids and boron induced tolerance of aluminum toxicity: A review. Ecotoxicol. Environ. Saf. 2018, 165, 25-35. [CrossRef]

17. Ma, J.F.; Furukawa, J. Recent progress in the research of external Al detoxification in higher plants: A minireview. J. Inorg. Biochem. 2003, 97, 46-51. [CrossRef]

18. Lyu, B.; Guo, X.; Gao, D.; Kou, M.; Yu, Y.; Ma, J.; Chen, S.; Wang, H.; Zhang, Y.; Bao, X. Auxin metabolic network regulates the plant response to metalloids stress. J. Hazard. Mater. 2020, 405, 124250.

19. Rahman, M.A.; Lee, S.H.; Ji, H.C.; Kabir, A.H.; Jones, C.S.; Lee, K.W. Importance of mineral nutrition for mitigating aluminum toxicity in plants on acidic soils: Current status and opportunities. Int. J. Mol. Sci. 2018, 19, 3073. [CrossRef] 
20. Zhou, J.; Li, Z.; Zhou, T.; Xin, Z.; Wu, L.; Luo, Y.; Christie, P. Aluminum toxicity decreases the phytoextraction capability by cadmium/zinc hyperaccumulator Sedum plumbizincicola in acid soils. Sci. Total Environ. 2020, 711, 134591. [CrossRef]

21. He, H.; Li, Y.; He, L.F. Aluminum toxicity and tolerance in Solanaceae plants. S. Afr. J. Bot. 2019, 123, 23-29. [CrossRef]

22. Jaiswal, S.K.; Naamala, J.; Dakora, F.D. Nature and mechanisms of aluminium toxicity, tolerance and amelioration in symbiotic legumes and rhizobia. Biol. Fertil. Soils 2018, 54, 309-318. [CrossRef] [PubMed]

23. Kopittke, P.M. Role of phytohormones in aluminium rhizotoxicity. Plant Cell Environ. 2016, 39, 2319-2328. [CrossRef]

24. Sun, L.; Zhang, M.; Liu, X.; Mao, Q.; Shi, C.; Kochian, L.V.; Liao, H. Aluminium is essential for root growth and development of tea plants (Camellia sinensis). J. Integr. Plant Biol. 2020, 62, 984-997. [CrossRef]

25. Liu, Y.; Tao, J.; Cao, J.; Zeng, Y.; Li, X.; Ma, J.; Huang, Z.; Jiang, M.; Sun, L. The beneficial effects of aluminum on the plant growth in Camellia japonica. J. Soil Sci. Plant Nutr. 2020, 20, 1799-1809. [CrossRef]

26. Sade, H.; Meriga, B.; Surapu, V.; Gadi, J.; Sunita, M.S.L.; Suravajhala, P.; Kavi Kishor, P.B. Toxicity and tolerance of aluminum in plants: Tailoring plants to suit to acid soils. BioMetals 2016, 29, 187-210. [CrossRef]

27. Yang, J.1.; Fan, W.; Zheng, S.j. jian Mechanisms and regulation of aluminum-induced secretion of organic acid anions from plant roots. J. Zhejiang Univ. Sci. B 2019, 20, 513-527. [CrossRef] [PubMed]

28. Qiu, W.; Wang, N.; Dai, J.; Wang, T.; Kochian, L.V.; Liu, J.; Zuo, Y. AhFRDL1-mediated citrate secretion contributes to adaptation to iron deficiency and aluminum stress in peanuts. J. Exp. Bot. 2019, 70, 2873-2886. [CrossRef]

29. Wu, Y.; Yang, Z.; How, J.; Xu, H.; Chen, L.; Li, K. Overexpression of a peroxidase gene (AtPrx64) of Arabidopsis thaliana in tobacco improves plant's tolerance to aluminum stress. Plant Mol. Biol. 2017, 95, 157-168. [CrossRef]

30. Ezaki, B.; Higashi, A.; Nanba, N.; Nishiuchi, T. An S-adenosyl methionine synthetase (SAMS) gene from Andropogon virginicus L. confers aluminum stress tolerance and facilitates epigenetic gene regulation in Arabidopsis thaliana. Front. Plant Sci. 2016, 7, 1-13. [CrossRef]

31. Zhang, L.; Wu, X.X.; Wang, J.; Qi, C.; Wang, X.; Wang, G.; Li, M.; Li, X.; Guo, Y.D. BoALMT1, an al-induced malate transporter in cabbage, enhances aluminum tolerance in Arabidopsis thaliana. Front. Plant Sci. 2018, 8, 1-9. [CrossRef] [PubMed]

32. Ribeiro, A.P.; de Souza, W.R.; Martins, P.K.; Vinecky, F.; Duarte, K.E.; Basso, M.F.; da Cunha, B.A.D.B.; Campanha, R.B.; de Oliveira, P.A.; Centeno, D.C.; et al. Overexpression of BdMATE gene improves aluminum tolerance in Setaria viridis. Front. Plant Sci. 2017, 8, 1-12. [CrossRef]

33. Zhou, Y.; Wang, Z.; Gong, L.; Chen, A.; Liu, N.; Li, S.; Sun, H.; Yang, Z.; You, J. Functional characterization of three MATE genes in relation to aluminum-induced citrate efflux from soybean root. Plant Soil 2019, 443, 121-138. [CrossRef]

34. Ma, Q.; Yi, R.; Li, L.; Liang, Z.; Zeng, T.; Zhang, Y.; Huang, H.; Zhang, X.; Yin, X.; Cai, Z.; et al. GsMATE encoding a multidrug and toxic compound extrusion transporter enhances aluminum tolerance in Arabidopsis thaliana. BMC Plant Biol. 2018, 18, 1-10. [CrossRef] [PubMed]

35. Li, N.; Meng, H.; Xing, H.; Liang, L.; Zhao, X.; Luo, K. Genome-wide analysis of MATE transporters and molecular characterization of aluminum resistance in Populus. J. Exp. Bot. 2017, 68, 5669-5683. [CrossRef]

36. Pooniya, V.; Palta, J.A.; Chen, Y.; Delhaize, E.; Siddique, K.H.M. Impact of the TaMATE1B gene on above and below-ground growth of durum wheat grown on an acid and $\mathrm{Al}^{3+}$-toxic soil. Plant Soil 2020, 447, 73-84. [CrossRef]

37. Xu, J.M.; Lou, H.Q.; Jin, J.F.; Chen, W.W.; Wan, J.X.; Fan, W.; Yang, J.L. A half-type ABC transporter FeSTAR1 regulates Al resistance possibly via UDP-glucose-based hemicellulose metabolism and Al binding. Plant Soil 2018, 432, 303-314. [CrossRef]

38. Chen, L.; Cai, Y.; Liu, X.; Guo, C.; Yao, W.; Sun, S.; Wu, C.; Jiang, B.; Han, T.; Hou, W. GmGRP-like gene confers Al tolerance in Arabidopsis. Sci. Rep. 2018, 8, 1-12. [CrossRef]

39. Cai, Z.; Xian, P.; Lin, R.; Cheng, Y.; Lian, T.; Ma, Q.; Nian, H. Characterization of the Soybean GmIREG Family Genes and the Function of GmIREG3 in Conferring Tolerance to Aluminum Stress. Int. J. Mol. Sci. 2020, 21, 497. [CrossRef]

40. Zhou, Y.; Yang, Z.; Xu, Y.; Sun, H.; Sun, Z.; Lin, B.; Sun, W.; You, J. Soybean NADP-malic enzyme functions in malate and citrate metabolism and contributes to their efflux under Al stress. Front. Plant Sci. 2018, 8, 1-11. [CrossRef]

41. Li, W.; Du, J.; Feng, H.; Wu, Q.; Xu, G.; Shabala, S.; Yu, L. Function of NHX-type transporters in improving rice tolerance to aluminum stress and soil acidity. Planta 2020, 251,1-13. [CrossRef]

42. Liu, W.; Feng, X.; Cao, F.; Wu, D.; Zhang, G.; Vincze, E.; Wang, Y.; Chen, Z.H.; Wu, F. An ATP binding cassette transporter HvABCB25 confers aluminum detoxification in wild barley. J. Hazard. Mater. 2020, 401, 123371. [CrossRef]

43. Sun, G.; Zhu, H.; Wen, S.; Liu, L.; Gou, L.; Guo, Z. Citrate synthesis and exudation confer Al resistance. Plant Soil 2020, 449, 319-329. [CrossRef]

44. Li, J.; Su, L.; Lv, A.; Li, Y.; Zhou, P.; An, Y. MsPG1 alleviated aluminum-induced inhibition of root growth by decreasing aluminum accumulation and increasing porosity and extensibility of cell walls in alfalfa (Medicago sativa). Environ. Exp. Bot. 2020, 175, 104045. [CrossRef]

45. Kariya, K.; Sameeullah, M.; Sasaki, T.; Yamamoto, Y. Overexpression of the sucrose transporter gene NtSUT1 alleviates aluminuminduced inhibition of root elongation in tobacco (Nicotiana tabacum L.). Soil Sci. Plant Nutr. 2017, 63, 45-54. [CrossRef]

46. Wang, M.; Qiao, J.Y.; Yu, C.L.; Chen, H.; Sun, C.D.; Huang, L.Z.; Li, C.Y.; Geisler, M.; Qian, Q.; Jiang, D.A.; et al. The auxin influx carrier, OsAUX3, regulates rice root development and responses to aluminium stress. Plant Cell Environ. 2019, 42, 1125-1138. [CrossRef]

47. Lou, H.Q.; Fan, W.; Xu, J.M.; Gong, Y.L.; Jin, J.F.; Chen, W.W.; Liu, L.Y.; Hai, M.R.; Yang, J.L.; Zheng, S.J. An oxalyl-CoA synthetase is involved in oxalate degradation and aluminum tolerance. Plant Physiol. 2016, 172, 1679-1690. [CrossRef] 
48. Lou, H.Q.; Gong, Y.L.; Fan, W.; Xu, J.M.; Liu, Y.; Cao, M.J.; Wang, M.H.; Yang, J.L.; Zheng, S.J. A formate dehydrogenase confers tolerance to aluminum and low pH. Plant Physiol. 2016, 171, 294-305. [CrossRef] [PubMed]

49. Luo, H.; He, C.; Han, L. Heterologous expression of ZjOMT from Zoysia japonica in Escherichia coli confers aluminum resistance through melatonin production. PLoS ONE 2018, 13, e0196952. [CrossRef]

50. Du, H.; Huang, Y.; Qu, M.; Li, Y.; Hu, X.; Yang, W.; Li, H.; He, W.; Ding, J.; Liu, C.; et al. A maize ZmAT6 gene confers aluminum tolerance via reactive oxygen species scavenging. Front. Plant Sci. 2020, 11, 1-12. [CrossRef] [PubMed]

51. Zhang, M.; Lu, X.; Li, C.; Zhang, B.; Zhang, C.; Zhang, X.S.; Ding, Z. Auxin efflux carrier ZmPGP1 mediates root growth inhibition under aluminum stress. Plant Physiol. 2018, 177, 819-832. [CrossRef]

52. Zhang, X.; Long, Y.; Huang, J.; Xia, J. Molecular mechanisms for coping with al toxicity in plants. Int. J. Mol. Sci. 2019, $20,1551$. [CrossRef]

53. Pin, M.A.; Magalhaes, J.V.; Alves, V.M.C.; Kochian, L.V. The physiology and biophysics of an aluminum tolerance mechanism based on root citrate exudation in maize. Plant Physiol. 2002, 129, 1194-1206.

54. Ligaba, A.; Dreyer, I.; Margaryan, A.; Schneider, D.J.; Kochian, L.; Piñeros, M. Functional, structural and phylogenetic analysis of domains underlying the Al sensitivity of the aluminum-activated malate/anion transporter, TaALMT1. Plant J. 2013, 76, 766-780. [CrossRef]

55. Hoekenga, O.A.; Maron, L.G.; Piñeros, M.A.; Cançado, G.M.A.; Shaff, J.; Kobayashi, Y.; Ryan, P.R.; Dong, B.; Delhaize, E.; Sasaki, T.; et al. AtALMT1, which encodes a malate transporter, is identified as one of several genes critical for aluminum tolerance in Arabidopsis. Proc. Natl. Acad. Sci. USA 2006, 103, 9738-9743. [CrossRef] [PubMed]

56. Kobayashi, Y.; Hoekenga, O.A.; Itoh, H.; Nakashima, M.; Saito, S.; Shaff, J.E.; Maron, L.G.; Piñeros, M.A.; Kochian, L.V.; Koyama, H. Characterization of AtALMT1 expression in aluminum-inducible malate release and its role for rhizotoxic stress tolerance in Arabidopsis. Plant Physiol. 2007, 145, 843-852. [CrossRef] [PubMed]

57. Gruber, B.D.; Ryan, P.R.; Richardson, A.E.; Tyerman, S.D.; Ramesh, S.; Hebb, D.M.; Howitt, S.M.; Delhaize, E. HvALMT1 from barley is involved in the transport of organic anions. J. Exp. Bot. 2010, 61, 1455-1467. [CrossRef] [PubMed]

58. Ligaba, A.; Katsuhara, M.; Ryan, P.R.; Shibasaka, M.; Matsumoto, H. The BnALMT1 and BnALMT2 genes from rape encode aluminum-activated malate transporters that enhance the aluminum resistance of plant cells. Plant Physiol. 2006, 142, 1294-1303. [CrossRef]

59. Ligaba, A.; Katsuhara, M.; Sakamoto, W.; Matsumoto, H. The BnALMT1 protein that is an aluminum-activated malate transporter is localized in the plasma membrane. Plant Signal. Behav. 2007, 2, 255-257. [CrossRef]

60. Ligaba, A.; Maron, L.; Shaff, J.; Kochian, L.; Piñeros, M. Maize ZmALMT2 is a root anion transporter that mediates constitutive root malate efflux. Plant Cell Environ. 2012, 35, 1185-1200. [CrossRef]

61. Chen, Z.C.; Yokosho, K.; Kashino, M.; Zhao, F.J.; Yamaji, N.; Ma, J.F. Adaptation to acidic soil is achieved by increased numbers of cis-acting elements regulating ALMT1 expression in Holcus lanatus. Plant J. 2013, 76, 10-23. [PubMed]

62. Park, W.; Kim, H.S.; Park, T.W.; Lee, Y.H.; Ahn, S.J. Functional characterization of plasma membrane-localized organic acid transporter (CsALMT1) involved in aluminum tolerance in Camelina sativa L. Plant Biotechnol. Rep. 2017, 11, 181-192. [CrossRef]

63. Ma, X.; An, F.; Wang, L.; Guo, D.; Xie, G.; Liu, Z. Genome-wide identification of aluminum-activated malate transporter (ALMT) gene family in rubber trees (Hevea brasiliensis) highlights their involvement in aluminum detoxification. Forests 2020, 11, 142. [CrossRef]

64. Upadhyay, N.; Kar, D.; Deepak Mahajan, B.; Nanda, S.; Rahiman, R.; Panchakshari, N.; Bhagavatula, L.; Datta, S. The multitasking abilities of MATE transporters in plants. J. Exp. Bot. 2019, 70, 4643-4656. [CrossRef]

65. Liu, J.; Magalhaes, J.V.; Shaff, J.; Kochian, L.V. Aluminum-activated citrate and malate transporters from the MATE and ALMT families function independently to confer Arabidopsis aluminum tolerance. Plant J. 2009, 57, 389-399. [CrossRef] [PubMed]

66. Wu, X.; Li, R.; Shi, J.; Wang, J.; Sun, Q.; Zhang, H.; Xing, Y.; Qi, Y.; Zhang, N.; Guo, Y.D. Brassica oleracea MATE encodes a citrate transporter and enhances aluminum tolerance in Arabidopsis thaliana. Plant Cell Physiol. 2014, 55, 1426-1436. [CrossRef] [PubMed]

67. Sawaki, Y.; Kihara-Doi, T.; Kobayashi, Y.; Nishikubo, N.; Kawazu, T.; Kobayashi, Y.; Koyama, H.; Sato, S. Characterization of Al-responsive citrate excretion and citrate-transporting MATEs in Eucalyptus camaldulensis. Planta 2013, 237, 979-989. [CrossRef]

68. Lei, G.J.; Yokosho, K.; Yamaji, N.; Ma, J.F. Two MATE transporters with different subcellular localization are involved in Al tolerance in buckwheat. Plant Cell Physiol. 2017, 58, 2179-2189. [CrossRef]

69. Liu, J.; Li, Y.; Wang, W.; Gai, J.; Li, Y. Genome-wide analysis of MATE transporters and expression patterns of a subgroup of MATE genes in response to aluminum toxicity in soybean. BMC Genom. 2016, 17, 1-15. [CrossRef]

70. Wang, P.; Yu, W.; Zhang, J.; Rengel, Z.; Xu, J.; Han, Q.; Chen, L.; Li, K.; Yu, Y.; Chen, Q. Auxin enhances aluminium-induced citrate exudation through upregulation of GmMATE and activation of the plasma membrane $\mathrm{H}^{+}$-ATPase in soybean roots. Ann. Bot. 2016, 118, 933-940. [CrossRef]

71. Iguchi, A.; Sanmiya, K.; Watanabe, K. Identification of genes encoding ALMT and MATE transporters as candidate aluminum tolerance genes from a typical acid soil plant, Psychotria rubra (Rubiaceae). PeerJ 2019, 7, e7739. [CrossRef]

72. Melo, J.O.; Lana, U.G.P.; Piñeros, M.A.; Alves, V.M.C.; Guimarães, C.T.; Liu, J.; Zheng, Y.; Zhong, S.; Fei, Z.; Maron, L.G.; et al. Incomplete transfer of accessory loci influencing SbMATE expression underlies genetic background effects for aluminum tolerance in sorghum. Plant J. 2013, 73, 276-288. [CrossRef] [PubMed]

73. Liu, M.Y.; Chen, W.W.; Xu, J.M.; Fan, W.; Yang, J.L.; Zheng, S.J. The role of VuMATE1 expression in aluminium-inducible citrate secretion in rice bean (Vigna umbellata) roots. J. Exp. Bot. 2013, 64, 1795-1804. [CrossRef] [PubMed] 
74. Fan, W.; Lou, H.Q.; Gong, Y.L.; Liu, M.Y.; Cao, M.J.; Liu, Y.; Yang, J.L.; Zheng, S.J. Characterization of an inducible C2H2-type zinc finger transcription factor VuSTOP1 in rice bean (Vigna umbellata) reveals differential regulation between low $\mathrm{pH}$ and aluminum tolerance mechanisms. New Phytol. 2015, 208, 456-468. [CrossRef] [PubMed]

75. Yang, X.Y.; Yang, J.L.; Zhou, Y.; Piñeros, M.A.; Kochian, L.V.; Li, G.X.; Zheng, S.J. A de novo synthesis citrate transporter, Vigna umbellata multidrug and toxic compound extrusion, implicates in Al-activated citrate efflux in rice bean (Vigna umbellata) root apex. Plant Cell Environ. 2011, 34, 2138-2148. [CrossRef] [PubMed]

76. Liu, M.Y.; Lou, H.Q.; Chen, W.W.; Piñeros, M.A.; Xu, J.M.; Fan, W.; Kochian, L.V.; Zheng, S.J.; Yang, J.L. Two citrate transporters coordinately regulate citrate secretion from rice bean root tip under aluminum stress. Plant Cell Environ. 2018, 41, 809-822. [CrossRef] [PubMed]

77. Maron, L.G.; Piñeros, M.A.; Guimarães, C.T.; Magalhaes, J.V.; Pleiman, J.K.; Mao, C.; Shaff, J.; Belicuas, S.N.J.; Kochian, L.V. Two functionally distinct members of the MATE (multi-drug and toxic compound extrusion) family of transporters potentially underlie two major aluminum tolerance QTLs in maize. Plant J. 2010, 61, 728-740. [CrossRef] [PubMed]

78. Zhu, H.; Wu, J.; Jiang, Y.; Jin, J.; Zhou, W.; Wang, Y.; Han, G.; Zhao, Y.; Cheng, B. Genomewide analysis of MATE-type gene family in maize reveals microsynteny and their expression patterns under aluminum treatment. J. Genet. 2016, 95, 691-704. [CrossRef]

79. Semenova, E.V.; Kosareva, I.A.; Belimov, A.A. Aluminum exclusion from root zone and maintenance of nutrient uptake are principal mechanisms of Al tolerance in Pisum sativum L. Physiol. Mol. Biol. Plants 2017, 23, 851-863.

80. Klug, B.; Horst, W.J. Oxalate exudation into the root-tip water free space confers protection from aluminum toxicity and allows aluminum accumulation in the symplast in buckwheat (Fagopyrum esculentum). New Phytol. 2010, 187, 380-391. [CrossRef]

81. Zhang, J.; Wei, J.; Li, D.; Kong, X.; Rengel, Z.; Chen, L.; Yang, Y.; Cui, X.; Chen, Q. The role of the plasma membrane $\mathrm{H}^{+}-\mathrm{ATPase}$ in plant responses to aluminum toxicity. Front. Plant Sci. 2017, 8, 1-9. [CrossRef] [PubMed]

82. Yang, Y.; Wang, Q.L.; Geng, M.J.; Guo, Z.H.; Zhao, Z. Rhizosphere ph difference regulated by plasma membrane $\mathrm{H}^{+}$-ATPase is related to differential Al-tolerance of two wheat cultivars. Plant Soil Environ. 2011, 57, 201-206. [CrossRef]

83. Zhang, F.; Yan, X.; Han, X.; Tang, R.; Chu, M.; Yang, Y.; Yang, Y.H.; Zhao, F.; Fu, A.; Luan, S.; et al. A defective vacuolar proton pump enhances aluminum tolerance by reducing vacuole sequestration of organic acids. Plant Physiol. 2019, 181, 743-761. [CrossRef]

84. Kidd, P.S.; Llugany, M.; Poschenrieder, C.; Gunsé, B.; Barceló, J. The role of root exudates in aluminium resistance and siliconinduced amelioration of aluminium toxicity in three varieties of maize (Zea mays L.). J. Exp. Bot. 2001, 52, 1339-1352. [PubMed]

85. Ma, Z.; Lin, S. Transcriptomic revelation of phenolic compounds involved in aluminum toxicity responses in roots of cunninghamia lanceolata (lamb.) hook. Genes 2019, 10, 835. [CrossRef] [PubMed]

86. Chen, Y.; Huang, L.; Liang, X.; Dai, P.; Zhang, Y.; Li, B.; Lin, X.; Sun, C. Enhancement of polyphenolic metabolism as an adaptive response of lettuce (Lactuca sativa) roots to aluminum stress. Environ. Pollut. 2020, 261, 114230. [CrossRef]

87. Fu, Z.; Jiang, X.; Li, W.W.; Shi, Y.; Lai, S.; Zhuang, J.; Yao, S.; Liu, Y.; Hu, J.; Gao, L.; et al. Proanthocyanidin-aluminum complexes improve aluminum resistance and detoxification of Camellia sinensis. J. Agric. Food Chem. 2020, 68, 7861-7869. [CrossRef]

88. Yang, J.L.; Li, Y.Y.; Zhang, Y.J.; Zhang, S.S.; Wu, Y.R.; Wu, P.; Zheng, S.J. Cell wall polysaccharides are specifically involved in the exclusion of aluminum from the rice root apex. Plant Physiol. 2008, 146, 602-611. [CrossRef]

89. Huang, C.F.; Yamaji, N.; Mitani, N.; Yano, M.; Nagamura, Y.; Ma, J.F. A bacterial-type ABC transporter is involved in aluminum tolerance in rice. Plant Cell 2009, 21, 655-667. [CrossRef]

90. Che, J.; Yamaji, N.; Yokosho, K.; Shen, R.F.; Ma, J.F. Two genes encoding a bacterial-type ATP-binding cassette transporter are implicated in aluminum tolerance in buckwheat. Plant Cell Physiol. 2018, 59, 2502-2511. [CrossRef]

91. Fan, W.; Xu, J.M.; Wu, P.; Yang, Z.X.; Lou, H.Q.; Chen, W.W.; Jin, J.F.; Zheng, S.J.; Yang, J.L. Alleviation by abscisic acid of Al toxicity in rice bean is not associated with citrate efflux but depends on ABI5-mediated signal transduction pathways. J. Integr. Plant Biol. 2019, 61, 140-154. [CrossRef]

92. Yang, T.-Y.; Huang, W.-T.; Zhang, J.; Yang, L.-T.; Huang, Z.-R.; Wu, B.-S.; Lai, N.-W.; Chen, L.-S. Raised pH conferred the ability to maintain a balance between production and detoxification of reactive oxygen species and methylglyoxal in aluminum-toxic Citrus sinensis leaves and roots. Environ. Pollut. 2020, 268, 115676. [CrossRef] [PubMed]

93. Yang, X.Y.; Zeng, Z.H.; Yan, J.Y.; Fan, W.; Bian, H.W.; Zhu, M.Y.; Yang, J.L.; Zheng, S.J. Association of specific pectin methylesterases with Al-induced root elongation inhibition in rice. Physiol. Plant. 2013, 148, 502-511. [CrossRef]

94. Baylis, A.D.; Gragopoulou, C.; Davidson, K.J.; Birchall, J.D. Effects of silicon on the toxicity of aluminium to soybean. Commun. Soil Sci. Plant Anal. 1994, 25, 537-546. [CrossRef]

95. Kochian, L.V. Cellular mechanisms of aluminum toxicity and resistance in plants. Annu. Rev. Plant Physiol. Plant Mol. Biol. 1995, 46, 237-260. [CrossRef]

96. Yang, J.L.; Zhu, X.F.; Peng, Y.X.; Zheng, C.; Li, G.X.; Liu, Y.; Shi, Y.Z.; Zheng, S.J. Cell wall hemicellulose contributes significantly to aluminum adsorption and root growth in Arabidopsis. Plant Physiol. 2011, 155, 1885-1892. [CrossRef] [PubMed]

97. Yang, T.Y.; Cai, L.Y.; Qi, Y.P.; Yang, L.T.; Lai, N.W.; Chen, L.S. Increasing nutrient solution ph alleviated aluminum-induced inhibition of growth and impairment of photosynthetic electron transport chain in Citrus sinensis seedlings. BioMed Res. Int. 2019, 2019, 9058715. [CrossRef]

98. Yang, T.Y.; Qi, Y.P.; Huang, H.Y.; Wu, F.L.; Huang, W.T.; Deng, C.L.; Yang, L.T.; Chen, L.S. Interactive effects of pH and aluminum on the secretion of organic acid anions by roots and related metabolic factors in Citrus sinensis roots and leaves. Environ. Pollut. 2020, 262, 114303. [CrossRef] [PubMed] 
99. Kong, X.; Peng, Z.; Li, D.; Ma, W.; An, R.; Khan, D.; Wang, X.; Liu, Y.; Yang, E.; He, Y.; et al. Magnesium decreases aluminum accumulation and plays a role in protecting maize from aluminum-induced oxidative stress. Plant Soil 2020, 457, 71-81. [CrossRef]

100. Zhang, Z.; Liu, D.; Meng, H.; Li, S.; Wang, S.; Xiao, Z.; Sun, J.; Chang, L.; Luo, K.; Li, N. Magnesium alleviates aluminum toxicity by promoting polar auxin transport and distribution and root alkalization in the root apex in populus. Plant Soil 2020, 448 , 565-585. [CrossRef]

101. Li, J.Y.; Liu, J.; Dong, D.; Jia, X.; McCouch, S.R.; Kochian, L.V. Natural variation underlies alterations in Nramp aluminum transporter (NRAT1) expression and function that play a key role in rice aluminum tolerance. Proc. Natl. Acad. Sci. USA 2014, 111, 6503-6508. [CrossRef] [PubMed]

102. Xia, J.; Yamaji, N.; Kasai, T.; Ma, J.F. Plasma membrane-localized transporter for aluminum in rice. Proc. Natl. Acad. Sci. USA 2010, 107, 18381-18385. [CrossRef] [PubMed]

103. Nhan, P. Amelioration of aluminum toxicity on OM4900 rice seedlings by sodium silicate. Afr. J. Plant Sci. 2013, 7, $208-212$. [CrossRef]

104. Carr, H.P.; Lombi, E.; Küpper, H.; McGrath, S.P.; Wong, M.H. Accumulation and distribution of aluminium and other elements in tea (Camellia sinensis) leaves. Agronomie 2003, 23, 705-710. [CrossRef]

105. Negishi, T.; Oshima, K.; Hattori, M.; Kanai, M.; Mano, S.; Nishimura, M.; Yoshida, K. Tonoplast-and plasma membrane-localized aquaporin-family transporters in Blue Hydrangea Sepals of Aluminum Hyperaccumulating Plant. PLoS ONE 2012, 7, e43189. [CrossRef]

106. Lu, M.; Yang, G.; Li, P.; Wang, Z.; Fu, S.; Zhang, X.; Chen, X.; Shi, M.; Ming, Z.; Xia, J. Bioinformatic and functional analysis of a key determinant underlying the substrate selectivity of the al transporter, Nrat1. Front. Plant Sci. 2018, 9, 1-9. [CrossRef] [PubMed]

107. Larsen, P.B.; Geisler, M.J.B.; Jones, C.A.; Williams, K.M.; Cancel, J.D. ALS3 encodes a phloem-localized ABC transporter-like protein that is required for aluminum tolerance in Arabidopsis. Plant J. 2005, 41, 353-363. [CrossRef] [PubMed]

108. Lei, G.J.; Yokosho, K.; Yamaji, N.; Fujii-Kashino, M.; Ma, J.F. Functional characterization of two half-size ABC transporter genes in aluminium-accumulating buckwheat. New Phytol. 2017, 215, 1080-1089. [CrossRef]

109. Ezaki, B.; Takahashi, K.; Utsumi, K.; Higashi, A. A half-type AvABCG1 transporter derived from Andropogon virginicus L. confers aluminum tolerance. Environ. Exp. Bot. 2015, 118, 21-31. [CrossRef]

110. Wang, Y.; Li, R.; Li, D.; Jia, X.; Zhou, D.; Li, J.; Lyi, S.M.; Hou, S.; Huang, Y.; Kochian, L.V.; et al. NIP1;2 is a plasma membranelocalized transporter mediating aluminum uptake, translocation, and tolerance in Arabidopsis. Proc. Natl. Acad. Sci. USA 2017, 114, 5047-5052. [CrossRef]

111. Hazak, O.; Mamon, E.; Lavy, M.; Sternberg, H.; Behera, S.; Schmitz-Thom, I.; Bloch, D.; Dementiev, O.; Gutman, I.; Danziger, T.; et al. A novel $\mathrm{Ca}^{2+}$-binding protein that can rapidly transduce auxin responses during root growth. PLoS Boil. 2019, 17, e3000085. [CrossRef] [PubMed]

112. Kar, D.; Pradhan, A.A.; Datta, S. The role of solute transporters in aluminium toxicity and tolerance. Physiol. Plant. 2020. [CrossRef]

113. Lan, T.; You, J.; Kong, L.; Yu, M.; Liu, M.; Yang, Z. The interaction of salicylic acid and $\mathrm{Ca}^{2+}$ alleviates aluminum toxicity in soybean (Glycine max L.). Plant Physiol. Biochem. 2016, 98, 146-154. [CrossRef]

114. Su, L.; Lv, A.; Wen, W.; Zhou, P.; An, Y. Auxin is involved in magnesium-mediated photoprotection in photosystems of alfalfa seedlings under aluminum stress. Front. Plant Sci. 2020, 11, 1-17. [CrossRef]

115. Chen, Z.C.; Yamaji, N.; Motoyama, R.; Nagamura, Y.; Ma, J.F. Up-regulation of a magnesium transporter gene OsMGT1 is required for conferring aluminum tolerance in rice. Plant Physiol. 2012, 159, 1624-1633. [CrossRef]

116. Li, D.; Ma, W.; Wei, J.; Mao, Y.; Peng, Z.; Zhang, J.; Kong, X.; Han, Q.; Fan, W.; Yang, Y.; et al. Magnesium promotes root growth and increases aluminum tolerance via modulation of nitric oxide production in Arabidopsis. Plant Soil 2019, 1-13. [CrossRef]

117. Vera-Villalobos, H.; Lunario-Delgado, L.; Pérez-Retamal, D.; Román, D.; Leiva, J.C.; Zamorano, P.; Mercado-Seguel, A.; Gálvez, A.S.; Benito, C.; Wulff-Zottele, C. Sulfate nutrition improves short-term $\mathrm{Al}^{3+}$-stress tolerance in roots of Lolium perenne L. Plant Physiol. Biochem. 2020, 148, 103-113. [CrossRef]

118. Yamamoto, Y.; Kobayashi, Y.; Devi, S.R.; Rikiishi, S.; Matsumoto, H. Oxidative stress triggered by aluminum in plant roots. Plant Soil 2003, 255, 239-243. [CrossRef]

119. Sun, C.; Liu, L.; Zhou, W.; Lu, L.; Jin, C.; Lin, X. Aluminum induces distinct changes in the metabolism of reactive oxygen and nitrogen species in the roots of two wheat genotypes with different aluminum resistance. J. Agric. Food Chem. 2017, 65, 9419-9427. [CrossRef] [PubMed]

120. Basu, U.; Good, A.G.; Taylor, G.J. Transgenic Brassica napus plants overexpressing aluminium-induced mitochondrial manganese superoxide dismutase cDNA are resistant to aluminium. Plant Cell Environ. 2001, 24, 1269-1278. [CrossRef]

121. Ezaki, B.; Gardner, R.C.; Ezaki, Y.; Matsumoto, H. Expression of aluminum-induced genes in transgenic Arabidopsis plants can ameliorate aluminum stress and/or oxidative stress. Plant Physiol. 2000, 122, 657-665. [CrossRef] [PubMed]

122. Guo, Y.; Qiao, D.; Yang, C.; Chen, J.; Li, Y.; Liang, S.; Lin, K.; Chen, Z. Genome-wide identification and expression analysis of SABATH methyltransferases in tea plant (Camellia sinensis): Insights into their roles in plant defense responses. Plant Signal. Behav. 2020, 15, 1804684. [CrossRef] [PubMed] 
123. Jin, J.F.; Wang, Z.Q.; He, Q.Y.; Wang, J.Y.; Li, P.F.; Xu, J.M.; Zheng, S.J.; Fan, W.; Yang, J.L. Genome-wide identification and expression analysis of the NAC transcription factor family in tomato (Solanum lycopersicum) during aluminum stress. BMC Genom. 2020, 21, 1-14. [CrossRef] [PubMed]

124. Liu, Y.; Xu, J.; Guo, S.; Yuan, X.; Zhao, S.; Tian, H.; Dai, S.; Kong, X.; Ding, Z. AtHB7/12 regulate root growth in response to aluminum stress. Int. J. Mol. Sci. 2020, 21, 4080. [CrossRef]

125. Li, C.X.; Yan, J.Y.; Ren, J.Y.; Sun, L.; Xu, C.; Li, G.X.; Ding, Z.J.; Zheng, S.J. A WRKY transcription factor confers aluminum tolerance via regulation of cell wall modifying genes. J. Integr. Plant Biol. 2019, 62, 1176-1192. [CrossRef]

126. Li, G.Z.; Wang, Z.Q.; Yokosho, K.; Ding, B.; Fan, W.; Gong, Q.Q.; Li, G.X.; Wu, Y.R.; Yang, J.L.; Ma, J.F.; et al. Transcription factor WRKY22 promotes aluminum tolerance via activation of OsFRDL4 expression and enhancement of citrate secretion in rice (Oryza sativa). New Phytol. 2018, 219, 149-162. [CrossRef] [PubMed]

127. Arun, A.; Yuriko, D.; Sanjib, K.; Panda, K. Characterization of CcSTOP1; a C2H2-type transcription factor regulates Al tolerance gene in pigeonpea. Planta 2017, 247, 201-214.

128. Kundu, A.; Das, S.; Basu, S.; Kobayashi, Y.; Kobayashi, Y.; Koyama, H.; Ganesan, M. GhSTOP1, a C2H2 type zinc finger transcription factor is essential for aluminum and proton stress tolerance and lateral root initiation in cotton. Plant Biol. 2019, 21, 35-44. [CrossRef]

129. Zhou, Y.; Yang, Z.M.; Gong, L.; Liu, R.K.; Sun, H.R.; You, J.F. Molecular characterization of GmSTOP1 homologs in soybean under $\mathrm{Al}$ and proton stress. Plant Soil 2018, 427, 213-230. [CrossRef]

130. Liu, Y.T.; Shi, Q.H.; Cao, H.J.; Ma, Q.B.; Nian, H.; Zhang, X.X. Heterologous expression of a Glycine soja C2H2 zinc finger gene improves aluminum tolerance in Arabidopsis. Int. J. Mol. Sci. 2020, 21, 2754. [CrossRef] [PubMed]

131. Wu, L.; Guoa, Y.; Caia, S.; Kuanga, L.; Shena, Q.; Wu, D.; Zhanga, G. A zinc finger transcription factor HvATF1 regulates aluminum tolerance in barley. J. Exp. Bot. 2020, 71, 6512-6523. [CrossRef] [PubMed]

132. Ito, H.; Kobayashi, Y.; Yamamoto, Y.Y.; Koyama, H. Characterization of NtSTOP1-regulating genes in tobacco under aluminum stress. Soil Sci. Plant Nutr. 2019, 65, 251-258. [CrossRef]

133. Che, J.; Tsutsui, T.; Yokosho, K.; Yamaji, N.; Ma, J.F. Functional characterization of an aluminum (Al)-inducible transcription factor, ART2, revealed a different pathway for Al tolerance in rice. New Phytol. 2018, 220, 209-218. [CrossRef] [PubMed]

134. Huang, S.; Gao, J.; You, J.; Liang, Y.; Guan, K.; Yan, S.; Zhan, M.; Yang, Z. Identification of STOP1-like proteins associated with aluminum tolerance in sweet sorghum (Sorghum bicolor L.). Front. Plant Sci. 2018, 9, 258. [CrossRef]

135. Zhang, X.; Li, L.; Yang, C.; Cheng, Y.; Han, Z.; Cai, Z.; Nian, H.; Ma, Q. GsMAS1 encoding a MADS-box transcription factor enhances the tolerance to aluminum stress in Arabidopsis thaliana. Int. J. Mol. Sci. 2020, 21, 2004. [CrossRef]

136. Feng, X.; Liu, W.; Dai, H.; Qiu, Y.; Zhang, G.; Chen, Z.-H.; Wu, F. HvHOX9, a novel homeobox leucine zipper transcription factor revealed by root miRNA and RNA sequencing in tibetan wild barley, positively regulates Al tolerance. J. Exp. Bot. 2020, 71, 6057-6073. [CrossRef]

137. An, J.P.; Wang, X.N.; Yao, J.F.; Ren, Y.R.; You, C.X.; Wang, X.F.; Hao, Y.J. Apple MdMYC2 reduces aluminum stress tolerance by directly regulating MdERF3 gene. Plant Soil 2017, 418, 255-266. [CrossRef]

138. Lou, H.Q.; Fan, W.; Jin, J.F.; Xu, J.M.; Chen, W.W.; Yang, J.L.; Zheng, S.J. A NAC-type transcription factor confers aluminium resistance by regulating cell wall-associated receptor kinase 1 and cell wall pectin. Plant. Cell Environ. 2020, 43, 463-478. [CrossRef]

139. Zhang, Y.; Zhang, J.; Guo, J.; Zhou, F.; Singh, S.; Xu, X.; Xie, Q.; Yang, Z.; Huang, C.F. F-box protein RAE1 regulates the stability of the aluminum-resistance transcription factor STOP1 in Arabidopsis. Proc. Natl. Acad. Sci. USA 2019, 116, 319-327. [CrossRef]

140. Guo, J.; Zhang, Y.; Gao, H.; Li, S.; Wang, Z.-Y.; Huang, C.-F. Mutation of HPR1 encoding a component of the THO/TREX complex reduces STOP1 accumulation and aluminium resistance in Arabidopsis thaliana. New Phytol. 2020, 228, 179-193. [CrossRef]

141. Fang, Q.; Zhang, J.; Zhang, Y.; Fan, N.; van den Burg, H.A.; Huang, C.F. Regulation of aluminum-resistance in Arabidopsis involves the SUMOylation of the zinc finger transcription factor STOP1. Plant Cell 2020, 32, 3921-3938. [CrossRef]

142. Tsutsui, T.; Yamaji, N.; Feng Ma, J. Identification of a cis-acting element of ART1, a C2H2-type zinc-finger transcription factor for aluminum tolerance in rice. Plant Physiol. 2011, 156, 925-931. [CrossRef]

143. Qin, H.; He, L.; Huang, R. The coordination of ethylene and other hormones in primary root development. Front. Plant Sci. 2019, 10, 874. [CrossRef]

144. Yang, Z.B.; Geng, X.; He, C.; Zhang, F.; Wang, R.; Horst, W.J.; Ding, Z. TAA1-regulated local auxin biosynthesis in the rootapex transition zone mediates the aluminum-induced inhibition of root growth in Arabidopsis. Plant Cell 2014, 26, $2889-2904$. [CrossRef]

145. Lv, B.; Yan, Z.; Tian, H.; Zhang, X.; Ding, Z. Local auxin biosynthesis mediates plant growth and development. Trends Plant Sci. 2019, 24, 6-9. [CrossRef]

146. Liu, G.; Gao, S.; Tian, H.; Wu, W.; Robert, H.S.; Ding, Z. Local transcriptional control of YUCCA regulates auxin promoted root-growth inhibition in response to aluminium stress in Arabidopsis. PLoS Genet. 2016, 12, 1-25. [CrossRef] [PubMed]

147. Yang, Z.; Liu, G.; Liu, J.; Zhang, B.; Meng, W.; Müller, B.; Hayashi, K.; Zhang, X.; Zhao, Z.; De Smet, I.; et al. Synergistic action of auxin and cytokinin mediates aluminum-induced root growth inhibition in Arabidopsis. EMBO Rep. 2017, 18, 1213-1230. [CrossRef] [PubMed]

148. Bai, B.; Bian, H.; Zeng, Z.; Hou, N.; Shi, B.; Wang, J.; Zhu, M.; Han, N. MiR393-mediated auxin signaling regulation is involved in root elongation inhibition in response to toxic aluminum stress in barley. Plant Cell Physiol. 2017, 58, 426-439. [CrossRef] [PubMed] 
149. Wang, Q.; Nian, F.; Zhao, L.; Li, F.; Yang, H.; Yang, Y. Exogenous indole-3-acetic acid could reduce the accumulation of aluminum in root apex of wheat (Triticum aestivum L.) under Al stress. J. Soil Sci. Plant Nutr. 2013, 13, 534-543. [CrossRef]

150. Wang, S.; Yuan, S.; Su, L.; Lv, A.; Zhou, P.; An, Y. Aluminum toxicity in alfalfa (Medicago sativa) is alleviated by exogenous foliar IAA inducing reduction of $\mathrm{Al}$ accumulation in cell wall. Environ. Exp. Bot. 2017, 139, 1-13. [CrossRef]

151. Tan, D.-X.; Hardeland, R.; Manchester, L.C.; Korkmaz, A.; Ma, S.; Rosales-Corral, S.; Reiter, R.J. Functional roles of melatonin in plants, and perspectives in nutritional and agricultural science. J. Exp. Bot. 2012, 63, 577-597. [CrossRef]

152. Zhang, J.; Zeng, B.; Mao, Y.; Kong, X.; Wang, X.; Yang, Y.; Zhang, J.; Xu, J.; Rengel, Z.; Chen, Q. Melatonin alleviates aluminium toxicity through modulating antioxidative enzymes and enhancing organic acid anion exudation in soybean. Funct. Plant Biol. 2017, 44, 961-968. [CrossRef]

153. Zhang, J.; Li, D.; Wei, J.; Ma, W.; Kong, X.; Rengel, Z.; Chen, Q. Melatonin alleviates aluminum-induced root growth inhibition by interfering with nitric oxide production in Arabidopsis. Environ. Exp. Bot. 2019, 161, 157-165. [CrossRef]

154. Sun, C.; Lv, T.; Huang, L.; Liu, X.; Jin, C.; Lin, X. Melatonin ameliorates aluminum toxicity through enhancing aluminum exclusion and reestablishing redox homeostasis in roots of wheat. J. Pineal Res. 2020, 68, 1-11. [CrossRef] [PubMed]

155. Sun, P.; Tian, Q.Y.; Chen, J.; Zhang, W.H. Aluminium-induced inhibition of root elongation in Arabidopsis is mediated by ethylene and auxin. J. Exp. Bot. 2010, 61, 347-356. [CrossRef] [PubMed]

156. Li, L.; Ma, Q.; Nian, H.; Yang, C.; Li, X.; Cheng, Y.; Cai, Z. GsERF enhances aluminum tolerance through an ethylene-mediated pathway in Arabidopsis thaliana. BioRxiv 2020, 1-21. [CrossRef]

157. Reyna-Llorens, I.; Corrales, I.; Poschenrieder, C.; Barcelo, J.; Cruz-Ortega, R. Both aluminum and ABA induce the expression of an ABC-like transporter gene (FeALS3) in the Al-tolerant species Fagopyrum esculentum. Environ. Exp. Bot. 2015, 111, 74-82. [CrossRef]

158. Salazar-Chavarría, V.; Sánchez-Nieto, S.; Cruz-Ortega, R. Fagopyrum esculentum at early stages copes with aluminum toxicity by increasing ABA levels and antioxidant system. Plant Physiol. Biochem. 2020, 152, 170-176. [CrossRef] [PubMed]

159. Emamverdian, A.; Ding, Y.; Xie, Y.; Sangari, S. Silicon mechanisms to ameliorate heavy metal stress in plants. BioMed Res. Int. 2018, 2018, 1-10. [CrossRef]

160. Wang, Y.; Stass, A.; Horst, W.J. Apoplastic binding of aluminum is involved in silicon-induced amelioration of aluminum toxicity in maize. Plant Physiol. 2004, 136, 3762-3770. [CrossRef]

161. Prabagar, S.; Hodson, M.J.; Evans, D.E. Silicon amelioration of aluminium toxicity and cell death in suspension cultures of Norway spruce (Picea abies L. Karst.). Environ. Exp. Bot. 2011, 70, 266-276. [CrossRef]

162. Qian, L.; Chen, B.; Chen, M. Novel alleviation mechanisms of aluminum phytotoxicity via released biosilicon from rice strawderived biochars. Sci. Rep. 2016, 6, 1-11. [CrossRef]

163. De Freitas, L.B.; Fernandes, D.M.; Maia, S.C.M.; Fernandes, A.M. Effects of silicon on aluminum toxicity in upland rice plants. Plant Soil 2017, 420, 263-275. [CrossRef]

164. Pontigo, S.; Godoy, K.; Jiménez, H.; Gutiérrez-Moraga, A.; Mora, M.D.L.L.; Cartes, P. Silicon-mediated alleviation of aluminum toxicity by modulation of $\mathrm{Al} / \mathrm{Si}$ uptake and antioxidant performance in ryegrass plants. Front. Plant Sci. 2017, 8, 1-15. [CrossRef]

165. Kopittke, P.M.; Gianoncelli, A.; Kourousias, G.; Green, K.; McKenna, B.A. Alleviation of Al toxicity by Si is associated with the formation of Al-Si complexes in root tissues of sorghum. Front. Plant Sci. 2017, 8, 1-9. [CrossRef]

166. Cocker, K.M.; Evans, D.E.; Hodson, M.J. The amelioration of aluminium toxicity by silicon in wheat (Triticum aestivum L.): Malate exudation as evidence for an in planta mechanism. Planta 1998, 204, 318-323. [CrossRef]

167. Yan, L.; Riaz, M.; Wu, X.; Du, C.; Liu, Y.; Lv, B.; Jiang, C. Boron inhibits aluminum-induced toxicity to citrus by stimulating antioxidant enzyme activity. J. Environ. Sci. Health Part C 2018, 36, 145-163. [CrossRef]

168. Riaz, M.; Yan, L.; Wu, X.; Hussain, S.; Aziz, O.; Wang, Y.; Imran, M.; Jiang, C. Boron alleviates the aluminum toxicity in trifoliate orange by regulating antioxidant defense system and reducing root cell injury. J. Environ. Manag. 2018, 208, 149-158. [CrossRef] [PubMed]

169. Riaz, M.; Yan, L.; Wu, X.; Hussain, S.; Aziz, O.; Imran, M.; Rana, M.S.; Jiang, C. Boron reduces aluminum-induced growth inhibition, oxidative damage and alterations in the cell wall components in the roots of trifoliate orange. Ecotoxicol. Environ. Saf. 2018, 153, 107-115. [CrossRef] [PubMed]

170. Stass, A.; Kotur, Z.; Horst, W.J. Effect of boron on the expression of aluminium toxicity in Phaseolus vulgaris. Physiol. Plant. 2007, 131, 283-290. [CrossRef] [PubMed]

171. Yu, M.; Shen, R.; Xiao, H.; Xu, M.; Wang, H.; Wang, H.; Zeng, Q.; Bian, J. Boron alleviates aluminum toxicity in pea (Pisum sativum). Plant Soil 2009, 314, 87-98. [CrossRef]

172. Li, X.W.; Liu, J.Y.; Fang, J.; Tao, L.; Shen, R.F.; Li, Y.L.; Xiao, H.D.; Feng, Y.M.; Wen, H.X.; Guan, J.H.; et al. Boron supply enhances aluminum tolerance in root border cells of pea (Pisum sativum) by interacting with cell wall pectins. Front. Plant Sci. 2017, 8, 1-11. [CrossRef] [PubMed]

173. Li, X.; Li, Y.; Mai, J.; Tao, L.; Qu, M.; Liu, J.; Shen, R.; Xu, G.; Feng, Y.; Xiao, H.; et al. Boron alleviates aluminum toxicity by promoting root alkalization in transition zone via polar auxin transport. Plant Physiol. 2018, 177, 1254-1266. [CrossRef]

174. Riaz, M.; Wu, X.; Yan, L.; Hussain, S.; Aziz, O.; Shah, A.; Jiang, C. Boron supply alleviates al-induced inhibition of root elongation and physiological characteristics in rapeseed (Brassica napus L.). J. Plant Interact. 2018, 13, 270-276. [CrossRef]

175. Ruiz, J.M.; Rivero, R.M.; Romero, L. Boron increases synthesis of glutathione in sunflower plants subjected to aluminum stress. Plant Soil 2006, 279, 25-30. [CrossRef] 
176. Hossain, A.K.M.Z.; Hossain, M.A.; Koyama, H.; Hara, T. Effects of aluminum and boron supply on growth of seedlings among 15 cultivars of wheat (Triticum aestivum L.) grown in Bangladesh. Soil Sci. Plant Nutr. 2004, 50, 189-195. [CrossRef]

177. Zhu, C.Q.; Cao, X.C.; Zhu, L.F.; Hu, W.J.; Hu, A.Y.; Abliz, B.; Bai, Z.G.; Huang, J.; Liang, Q.D.; Sajid, H.; et al. Boron reduces cell wall aluminum content in rice (Oryza sativa) roots by decreasing $\mathrm{H}_{2} \mathrm{O}_{2}$ accumulation. Plant Physiol. Biochem. 2019, 138, 80-90. [CrossRef] [PubMed]

178. Yan, L.; Riaz, M.; Liu, J.; Liu, Y.; Zeng, Y.; Jiang, C. Boron reduces aluminum deposition in alkali-soluble pectin and cytoplasm to release aluminum toxicity. J. Hazard. Mater. 2020, 401, 123388. [CrossRef] [PubMed]

179. Yu, Y.; Zhou, W.; Liang, X.; Zhou, K.; Lin, X. Increased bound putrescine accumulation contributes to the maintenance of antioxidant enzymes and higher aluminum tolerance in wheat. Environ. Pollut. 2019, 252, 941-949. [CrossRef]

180. Yu, Y.; Zhou, W.; Zhou, K.; Liu, W.; Liang, X.; Chen, Y.; Sun, D.; Lin, X. Polyamines modulate aluminum-induced oxidative stress differently by inducing or reducing $\mathrm{H}_{2} \mathrm{O}_{2}$ production in wheat. Chemosphere 2018, 212, 645-653. [CrossRef]

181. Yu, Y.; Jin, C.; Sun, C.; Wang, J.; Ye, Y.; Zhou, W.; Lu, L.; Lin, X. Inhibition of ethylene production by putrescine alleviates aluminium-induced root inhibition in wheat plants. Sci. Rep. 2016, 6, 1-10. [CrossRef] [PubMed]

182. Zhu, C.Q.; Cao, X.C.; Bai, Z.G.; Zhu, L.F.; Hu, W.J.; Hu, A.Y.; Abliz, B.; Zhong, C.; Liang, Q.D.; Huang, J.; et al. Putrescine alleviates aluminum toxicity in rice (Oryza sativa) by reducing cell wall $\mathrm{Al}$ contents in an ethylene-dependent manner. Physiol. Plant. 2019, 167, 471-487. [CrossRef] [PubMed]

183. Jiang, D.; Hou, J.; Gao, W.; Tong, X.; Li, M.; Chu, X.; Chen, G. Exogenous spermidine alleviates the adverse effects of aluminum toxicity on photosystem II through improved antioxidant system and endogenous polyamine contents. Ecotoxicol. Environ. Saf. 2020, 207, 111265. [CrossRef] [PubMed]

184. Nahar, K.; Hasanuzzaman, M.; Suzuki, T.; Fujita, M. Polyamines-induced aluminum tolerance in mung bean: A study on antioxidant defense and methylglyoxal detoxification systems. Ecotoxicology 2017, 26, 58-73. [CrossRef]

185. Qu, X.; Zhou, J.; Masabni, J.; Yuan, J. Phosphorus relieves aluminum toxicity in oil tea seedlings by regulating the metabolic profiling in the roots. Plant Physiol. Biochem. 2020, 152, 12-22. [CrossRef]

186. Yao, H.; Zhang, S.; Zhou, W.; Liu, Y.; Liu, Y.; Wu, Y. The effects of exogenous malic acid in relieving aluminum toxicity in Pinus massoniana. Int. J. Phytoremediation 2020, 22, 669-678. [CrossRef] [PubMed]

187. Shetty, R.; Vidya, C.S.N.; Prakash, N.B.; Lux, A.; Vaculík, M. Aluminum toxicity in plants and its possible mitigation in acid soils by biochar: A review. Sci. Total Environ. 2021, 765, 142744. [CrossRef] [PubMed]

188. Lin, Q.; Zhang, L.; Riaz, M.; Zhang, M.; Xia, H.; Lv, B.; Jiang, C. Assessing the potential of biochar and aged biochar to alleviate aluminum toxicity in an acid soil for achieving cabbage productivity. Ecotoxicol. Environ. Saf. 2018, 161, 290-295. [CrossRef]

189. Xia, H.; Riaz, M.; Zhang, M.; Liu, B.; El-Desouki, Z.; Jiang, C. Biochar increases nitrogen use efficiency of maize by relieving aluminum toxicity and improving soil quality in acidic soil. Ecotoxicol. Environ. Saf. 2020, 196, 110531. [CrossRef]

190. Meena, V.S.; Meena, S.K.; Verma, J.P.; Kumar, A.; Aeron, A.; Mishra, P.K.; Bisht, J.K.; Pattanayak, A.; Naveed, M.; Dotaniya, M.L. Plant beneficial rhizospheric microorganism (PBRM) strategies to improve nutrients use efficiency: A review. Ecol. Eng. 2017, 107, 8-32. [CrossRef]

191. Shailendra Singh, G.G. Plant growth promoting rhizobacteria (PGPR): Current and future prospects for development of sustainable agriculture. J. Microb. Biochem. Technol. 2015, 07, 96-102. [CrossRef]

192. Zerrouk, I.Z.; Benchabane, M.; Khelifi, L.; Yokawa, K.; Ludwig-Müller, J.; Baluska, F. A Pseudomonas strain isolated from date-palm rhizospheres improves root growth and promotes root formation in maize exposed to salt and aluminum stress. J. Plant Physiol. 2016, 191, 111-119. [CrossRef] [PubMed]

193. Zerrouk, I.Z.; Rahmoune, B.; Khelifi, L.; Mounir, K.; Baluska, F.; Ludwig-Müller, J. Algerian Sahara PGPR confers maize root tolerance to salt and aluminum toxicity via ACC deaminase and IAA. Acta Physiol. Plant. 2019, 41, 1-10. [CrossRef]

194. Zerrouk, I.Z.; Rahmoune, B.; Auer, S.; Rößler, S.; Lin, T.; Baluska, F.; Dobrev, P.I.; Motyka, V.; Ludwig-Müller, J. Growth and aluminum tolerance of maize roots mediated by auxin- and cytokinin-producing Bacillus toyonensis requires polar auxin transport. Environ. Exp. Bot. 2020, 176, 104064. [CrossRef]

195. Silambarasan, S.; Logeswari, P.; Cornejo, P.; Kannan, V.R. Role of plant growth-promoting rhizobacterial consortium in improving the Vigna radiata growth and alleviation of aluminum and drought stresses. Environ. Sci. Pollut. Res. 2019, 26, 27647-27659. [CrossRef]

196. Silambarasan, S.; Logeswari, P.; Cornejo, P.; Abraham, J.; Valentine, A. Simultaneous mitigation of aluminum, salinity and drought stress in Lactuca sativa growth via formulated plant growth promoting Rhodotorula mucilaginosa CAM4. Ecotoxicol. Environ. Saf. 2019, 180, 63-72. [CrossRef]

197. Panhwar, Q.A.; Naher, U.A.; Radziah, O.; Shamshuddin, J.; Razi, I.M. Eliminating aluminum toxicity in an acid sulfate soil for rice cultivation using plant growth promoting bacteria. Molecules 2015, 20, 3628-3646. [CrossRef]

198. Farh, M.E.A.; Kim, Y.J.; Sukweenadhi, J.; Singh, P.; Yang, D.C. Aluminium resistant, plant growth promoting bacteria induce overexpression of aluminium stress related genes in Arabidopsis thaliana and increase the ginseng tolerance against aluminium stress. Microbiol. Res. 2017, 200, 45-52. [CrossRef]

199. Mora, M.d.l.L.; Demanet, R.; Acuña, J.J.; Viscardi, S.; Jorquera, M.; Rengel, Z.; Durán, P. Aluminum-tolerant bacteria improve the plant growth and phosphorus content in ryegrass grown in a volcanic soil amended with cattle dung manure. Appl. Soil Ecol. 2017, 115, 19-26. [CrossRef] 
200. Kang, J.P.; Huo, Y.; Yang, D.U.; Yang, D.C. Influence of the plant growth promoting rhizobium panacihumi on aluminum resistance in Panax ginseng. J. Ginseng Res. 2020, 1-8. [CrossRef]

201. Anwar, A.; Kim, J.K. Transgenic breeding approaches for improving abiotic stress tolerance: Recent progress and future perspectives. Int. J. Mol. Sci. 2020, 21, 2695. [CrossRef]

202. Wang, H.; Ji, F.; Zhang, Y.; Hou, J.; Liu, W.; Huang, J.; Liang, W. Interactions between hydrogen sulphide and nitric oxide regulate two soybean citrate transporters during the alleviation of aluminium toxicity. Plant Cell Environ. 2019, 42, 2340-2356. [CrossRef]

203. Yokosho, K.; Yamaji, N.; Mitani-Ueno, N.; Shen, R.F.; Ma, J.F. An aluminum-inducible IREG gene is required for internal detoxification of aluminum in buckwheat. Plant Cell Physiol. 2016, 57, 1169-1178. [CrossRef] [PubMed]

204. Huang, C.F.; Yamaji, N.; Chen, Z.; Ma, J.F. A tonoplast-localized half-size ABC transporter is required for internal detoxification of aluminum in rice. Plant J. 2012, 69, 857-867. [CrossRef]

205. Xia, J.; Yamaji, N.; Che, J.; Shen, R.F.; Ma, J.F. Differential expression of Nrat1 is responsible for Al-tolerance QTL on chromosome 2 in rice. J. Exp. Bot. 2014, 65, 4297-4304. [CrossRef] [PubMed]

206. Lu, M.; Wang, Z.; Fu, S.; Yang, G.; Shi, M.; Lu, Y.; Wang, X.; Xia, J. Functional characterization of the SbNrat1 gene in sorghum. Plant Sci. 2017, 262, 18-23. [CrossRef] [PubMed]

207. Wu, F.; Chi, Y.; Jiang, Z.; Xu, Y.; Xie, L.; Huang, F.; Wan, D.; Ni, J.; Yuan, F.; Wu, X.; et al. Hydrogen peroxide sensor HPCA1 is an LRR receptor kinase in Arabidopsis. Nature 2020, 578, 577-581. [CrossRef]

208. Jiang, Z.; Zhou, X.; Tao, M.; Yuan, F.; Liu, L.; Wu, F.; Wu, X.; Xiang, Y.; Niu, Y.; Liu, F.; et al. Plant cell-surface GIPC sphingolipids sense salt to trigger $\mathrm{Ca}^{2+}$ influx. Nature 2019, 572, 341-346. [CrossRef] 